\title{
Working
}

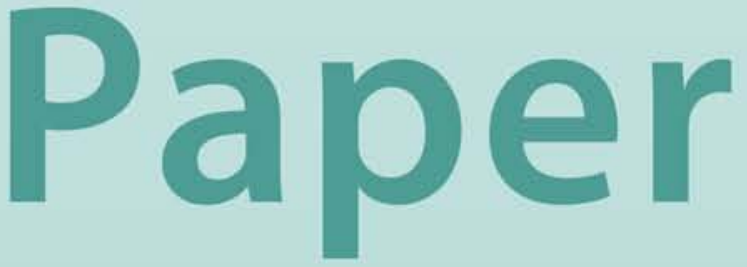


Financial Reforms in Sudan: Streamlining Bank Intermediation

Alexei Kireyev 


\title{
IMF Working Paper
}

Office in Geneva

\section{Financial Reforms in Sudan: Streamlining Bank Intermediation}

\author{
Prepared by Alexei Kireyev ${ }^{1}$ \\ Authorized for distribution by Grant B. Taplin
}

May 2001

\begin{abstract}
The views expressed in this Working Paper are those of the author(s) and do not necessarily represent those of the IMF or IMF policy. Working Papers describe research in progress by the author(s) and are published to elicit comments and to further debate.
\end{abstract}

The paper reviews the experience of financial reforms in Sudan with a view to assessing their macroeconomic impact and to shedding light on the question why such reforms have not yet brought about visible improvements in financial intermediation. The paper concludes that regardless of the progress achieved in recent years, deficiencies in the reform design, institutional weaknesses, shallow financial markets, shortcomings of the Islamic mode of finance, and strong seasonality remain key factors that constrain financial intermediation. Additional efforts, in particular in bank restructuring, credit instrument design, monetary policy management, and prudential regulation are needed to address the systemic problems of the financial sector and to make it capable of supporting private sector growth.

JEL Classification Numbers: E42, E52, G22, G28

Keywords: financial reform, monetary policy, Islamic finance, banking supervision, Sudan Author's E-Mail Address:akireyev@imf.org

${ }^{1}$ The author is grateful to Zuzana Brixiova, Pierre Dhonte, Patrick Megarbane, Inwon Song, Grant Taplin, and Milan Zavadjil for their helpful comments. The author was in the Middle Eastern Department when the main body of the paper was prepared. 
Introduction. 4

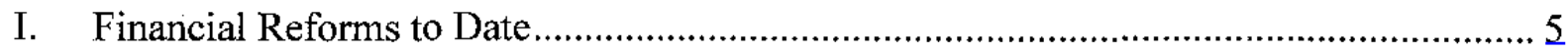

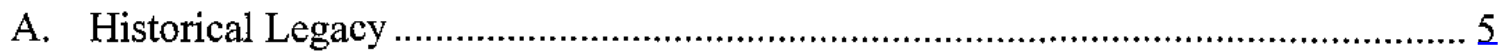

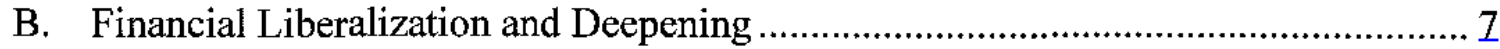

C. Bank Supervision and Prudential Regulations................................................... 9

D. Monetary Policy Instruments .................................................................... 11

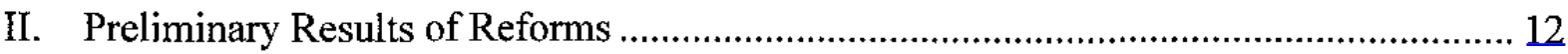

A. Impact on Level of Financial Intermediation.................................................. 12

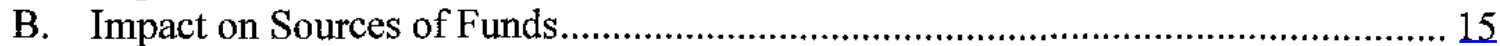

C. Impact on Credit to Private Sector................................................................ 17

D. Impact on Efficiency of Monetary Policy..................................................... 21

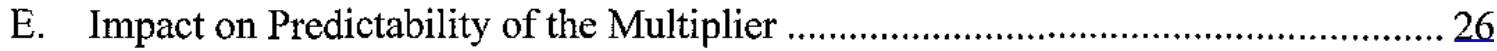

III. Key Impediments for the Success of Reforms ................................................... 29

A. Sequencing of Reforms ............................................................................ 29

B. Institutional Deficiencies ....................................................................... 31

C. Shallowness of Financial Markets …........................................................... 34

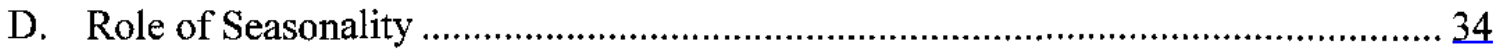

IV. Policy Challenges and International Experience ................................................ 38

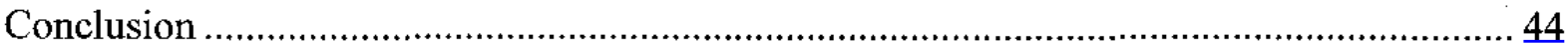

Figures

1. Sudan: Sequencing of Financial Reforms, 1990-2000 ............................................ 8

2. Sudan: Level of Financial Intermediation, 1990-99 _............................................ 14

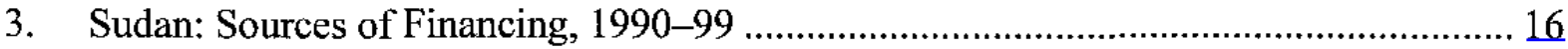

4. Sudan: Credit to Private Sector, 1990-99 .............................................................. 18

5. Sudan: Transmission of Monetary Policy, 1990-99............................................... 22

6. Sudan: Money Multiplier Components, 1990-99 …............................................... 27

7. Sudan: Stylized Sequencing of Reforms................................................................. 30

8. Sudan: Sectoral Credit Policy, 1990-2000 …............................................................ 32

9. Sudan: Seasonality in Monetary Aggregates, 1994-99 …........................................ 36

10. Sudan: Ramadan-related Seasonality in Real Money Demand, 1991-99 ................... 37 


\section{Tables}

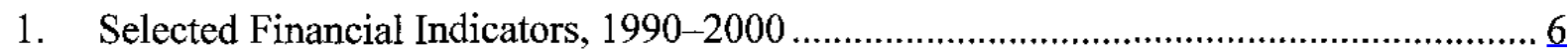

2. Prudential Ratios and Limits............................................................................. 10

3. Degree of BOS Control of Reserve Money Expansion ........................................ 24

Text Boxes

1. Monetary Policy in mid-1990s ......................................................................... 5

2. Reasons for the Decline of Real Credit to the Private Sector .................................... 20

3. Limitations of the Islamic Financial System ....................................................... 33

\section{Appendices}

1. Islamic Financial Instruments Used in Sudan................................................... 45

2. Evolution of Key Elements of Banking Supervision............................................. 46

3. Evolution of Monetary Policy Instruments.......................................................... 48

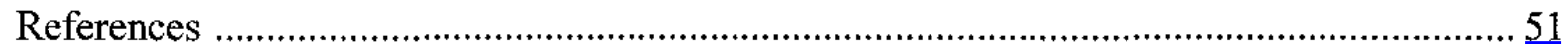


O ye who believe!

Devour not usury, doubling and quadrupling of money lent. We have prepared for those who disbelieve a painful doom.

Al-Qur'an, III: 130; IV: 161.

\section{INTRODUCTION}

After 1997, following several years of partial reform attempts, Sudan embarked upon a liberalization of its financial system, culminating, in 2000 , in the adoption of a comprehensive program of bank restructuring. Financial reform in Sudan is more than a mere sum of its parts. It is a complex fusion of historical legacy, difficult political compromises, dominating Islamic rules, traditionalist mentality, macrostabilization efforts, pure bank restructuring, external liberalization, and thorny social dilemmas. At this stage, only tentative conclusions can be drawn as the reforms have not yet been completed - they are still in their infancy, about four years old. They came after a stormy period of political repudiation, macroeconomic instability, and financial distress during the mid-1990s and culminated into an ambitious medium-term program of bank restructuring in the early $2000 \mathrm{~s}$.

The purpose of this paper is to shed light on the question of why, regardless of the persistent efforts in recent years to reform the financial sector, such reforms have not yet radically improved financial intermediation, which still remains a stumbling block to economic development in Sudan. Although the paper attempts to synthesize both the preliminary results of reforms, as well as key impediments, it is neither a comprehensive catalogue of achievements, nor an unquestionable recipe for the future. Thus, the conclusions in the paper should be treated as suggestions only, reflecting the author's personal views and understanding of the complex processes evolving in the Sudanese financial system.

The paper relies mainly on verbal exposition and deliberately avoids employing any heavy tools of econometric analysis, because erratic shifts in an agricultural economy, like the Sudanese, cannot be faithfully described by an econometric model. It rather uses logic and graphical illustrations as the main analytical tools. This paper is organized as follows: Part I briefly reviews the evolution of the financial system in Sudan in the 1990s and the recent history of financial reforms; Part II assesses the preliminary impact of reforms on financial intermediation, sources of funds, credit to the private sector, and monetary policy; Part III identifies key impediments to the success of the financial reforms; and, finally, Part IV reviews financial reform challenges still facing Sudan in the light of best practices in other countries close to Sudan in level of development. 


\section{Financial Reforms to Date}

\section{A. Historical Legacy}

Sudan has a complex financial system based entirely on Islamic principles. Sudan, which introduced elements of Islamic banking in 1984 and adopted them for the country's entire financial system in 1992, is one of very few countries in the world with its financial system built completely on Islamic principles. Sudan's financial system consists of the Bank of Sudan (BOS), the central bank responsible for the conduct of monetary and exchange rate policy, and 25 active commercial banks. The financial system includes: state-owned banks; banks owned jointly either by local and foreign capital, or by the government and private sector; foreign, specialized, and investment banks; and a number of nonbank financial entities, mainly insurance companies (Table 1). With the divestiture of government holdings in banks, the number of private banks and banks owned jointly increased from 12 in 1990 to 16 in 2000 . The share of private banks in total assets and deposits of the banking system increased from 43.2 percent in 1992 to 83.6 percent in 1999 , and from 39 percent to 75 percent, respectively. Two insolvent banks have been liquidated.

Throughout the history of the Sudanese financial system, directives have piled up, culminating in a bulky and largely unmanageable regulatory system in the mid-1990s. Sudan's financial system was characterized by cumbersome guidelines for credit allocation, centralized lending by the central bank to public enterprises, absence of indirect monetary policy instruments, fixed and negative in real terms cost of funds, lax banking

supervision, and an inadequate accounting system. Historically, all sectors of the economy have been subdivided into priority sectors, nonpriority sectors, and sectors prohibited from bank financing. The guidelines included maximum and minimum limits of lending to individual sectors, restrictions on financing trade in individual commodities, bank-by-bank credit limits, prior approval of large loans, geographical allocation of credit, etc. (Box 1).

\section{Box 1. Sudan: Monetary Policy in mid-1990s}

A snapshot taken directly from the BOS annual statement on monetary policy for 1996 gives an excellent indication of the bulkiness and unmanageability of the then-existing system. In 1996, the list of eleven priority sectors, which were supposed to receive 90 percent of total credit, was expanded by two additional sectors - transport and cooperatives. Out of the 90 percent of credit allocated to primary sectors, at least 40 percent should have been directed toward agriculture, of which 25 percent should have been for plant agriculture and 15 percent for livestock agriculture. Priority sectors in each state should have received, as credit, at least 50 percent of deposits collected from customers from this state. Minimum profit margins under Murabaha contracts were set in the range from 15 to 36 percent, with a minimum rate for agriculture, trade and exports of 30 percent, other priority sectors of 36 percent, craftsmen of 20 percent, and small producers of 15 percent. Customers' share under the Musharaka contracts ranged from 10 to 60 percent depending on the sector-in financing for local trade, customers' share should have been not less than 60 percent, for exports and cooperatives for the purposes of production not less than 20 percent, for other cooperatives not less than 30 percent, for craftsmen not less than 15 percent, for family producers not less than 10 percent, and for other primary sectors not less than 25 percent. 
Table 1. Sudan: Selected Financial Indicators, 1990-2000

\begin{tabular}{|c|c|c|c|c|c|c|c|c|c|c|c|c|c|c|}
\hline \multirow[b]{3}{*}{ Institutional structure } & \multicolumn{7}{|c|}{ Pre-reform period } & \multicolumn{4}{|c|}{ Reform period } & \multicolumn{3}{|c|}{\begin{tabular}{|c|} 
Average \\
$1991-1994-1997-$
\end{tabular}} \\
\hline & 1990 & 1991 & 1992 & 1993 & 1994 & 1995 & 1996 & 1997 & 1998 & 1999 & 2000 & 1993 & 1996 & 2000 \\
\hline & & & & & & & & & & & & & & \\
\hline Total number of banks & 28 & 28 & 29 & 29 & 28 & 27 & 27 & 27 & 27 & 26 & 25 & 29 & 27 & 26 \\
\hline State-owned banks & 5 & 5 & 4 & 4 & 4 & 2 & 2 & 2 & 2 & 2 & 2 & 5 & 3 & 2 \\
\hline Joint banks & 12 & 12 & 14 & 16 & 16 & 17 & 17 & 17 & 17 & 16 & 16 & 14 & 17 & 17 \\
\hline Foreign+local capital & 10 & 10 & 10 & 11 & 11 & 11 & 11 & 11 & 11 & 11 & 11 & 10 & 11 & 11 \\
\hline Government + private capital & 2 & 2 & 4 & 5 & 5 & 6 & 6 & 6 & 6 & 5 & 5 & 3 & 6 & 6 \\
\hline Foreign banks & 6 & 6 & 6 & 4 & 4 & 4 & 4 & 4 & 3 & 3 & 3 & 6 & 4 & 3 \\
\hline Specialized banks & 4 & 4 & 4 & 4 & 3 & 3 & 3 & 3 & 3 & 3 & 3 & 4 & 3 & 3 \\
\hline Investment banks & 1 & 1 & 1 & l & 1 & 1 & 1 & 1 & 2 & 2 & 1 & 1 & 1 & 2 \\
\hline Index in real terms & & & & & & & $(1997$ & $=100$ & & & & & & \\
\hline Reserve money & 251 & 235 & 206 & 165 & 112 & 116 & 98 & 100 & 120 & 138 & 147 & 214 & 109 & 126 \\
\hline Broad money & 168 & 184 & 173 & 168 & 121 & 124 & 97 & 100 & 118 & 127 & 137 & 173 & 114 & 120 \\
\hline Gross credit & 229 & 231 & 178 & 167 & 123 & 125 & 96 & 100 & 105 & 102 & 132 & 201 & 115 & 110 \\
\hline To government & 229 & 188 & 178 & 164 & 140 & 131 & 100 & 100 & 105 & 129 & 130 & 190 & 124 & 116 \\
\hline To privat & 591 & 299 & 257 & 179 & 122 & 107 & 113 & 100 & 104 & 88 & 108 & 331 & 114 & 100 \\
\hline To public & 690 & 349 & 301 & 208 & 124 & 112 & 116 & 100 & 136 & 271 & 552 & 387 & 118 & 265 \\
\hline BOS credit to banks & 320 & 162 & 145 & 114 & 108 & 94 & 107 & 100 & 179 & 174 & 153 & 185 & 103 & 151 \\
\hline Total deposits & 2161 & 1093 & 817 & 416 & 295 & 184 & 116 & 100 & 114 & 117 & 138 & 1122 & 198 & 117 \\
\hline In local currency & 93 & 47 & 38 & 128 & 43 & 25 & 12 & 100 & 112 & 120 & 154 & 76 & 26 & 121 \\
\hline In foreign currency & 216 & 183 & 187 & 171 & 123 & 128 & 94 & 100 & 117 & 114 & 118 & 189 & 115 & 112 \\
\hline Moneta & & & & & & & & & & & & & & \\
\hline Reservesis & 55.6 & 40.4 & 40.7 & 26.4 & 19.3 & 21.2 & 25.8 & 26.6 & 23.1 & 26.5 & 32.3 & 40.8 & 822.1 & 27.1 \\
\hline Currency/deposits & 69.2 & 62.1 & 49.9 & 54.3 & 57.5 & 54.4 & 61.6 & 57.8 & 65.8 & 72.2 & 62.8 & 58.8 & 57.8 & 64.6 \\
\hline Multiplier & 1.7 & 1.8 & 1.6 & 1.9 & 2.0 & 2.0 & 1.8 & 1.8 & 1.8 & 1.7 & 1.8 & 1.7 & 1.9 & 1.8 \\
\hline Currency/broad money & 40.9 & 38.3 & 33.3 & 35.2 & 36.5 & 35.2 & 38.1 & 36.6 & 39.7 & 41.9 & 38.6 & 36.9 & 36.6 & 39.2 \\
\hline Currency in circulation/rese & 52.9 & 57.6 & 52.5 & 65.4 & 73.2 & 69.6 & 68.4 & 67.1 & 72.8 & 70.9 & 68.6 & 57.1 & 70.4 & 69.9 \\
\hline Credit to private & 19.6 & 19.6 & 20.5 & 23.0 & 32.0 & 31.7 & 34.3 & 36.2 & 35.8 & 31.1 & 29.5 & 20.7 & $\begin{array}{l}7 \quad 32.7\end{array}$ & 33.1 \\
\hline Foreign currency deposits/total dep & 7.9 & 19.8 & 29.6 & 49.8 & 46.5 & 49.7 & 42.4 & 44.3 & 45.3 & 43.2 & 37.8 & 26.8 & 86.2 & 42.7 \\
\hline Financia & & & & & (In po & ercent, & unless i & dicate & ed othe & rwise) & & & & \\
\hline Return on investment deposits & & & & & & & & & & & & & & \\
\hline In local currency & n.d. & n.a. & n.a. & n.a. & n.a. & 40.0 & 36.0 & 34.0 & 30.0 & 24.0 & 21.0 & n.a. & 38.0 & 27.3 \\
\hline In foreign currency & n.a. & n.a. & n.a. & n.a. & n.a. & n.a. & n.a. & n.a. & n.a. & 16 & 14 & n.d. & n.a. & 15.0 \\
\hline Murabaha lending rate & n.a. & n.a. & n.a. & n.a. & n.a. & 27.2 & 33.0 & 42.0 & 30.0 & 29.0 & 25.6 & 11. d. & 30.1 & 31.7 \\
\hline Structu & & & & & & & & & & & & & & \\
\hline Total de & 100 & 100 & 100 & 100 & 100 & 100 & 100 & 100 & 100 & 100 & 100 & 100 & 100 & 100 \\
\hline Current & 67 & 68 & 54 & 38 & 42 & 38 & 46 & 43 & 43 & 47 & 46 & 57 & 42 & 45 \\
\hline Investmer & 12 & 12 & 28 & 22 & 6 & 5 & 7 & 8 & 8 & 8 & 10 & 19 & 6 & 8 \\
\hline Saving deposits & 4 & 4 & 3 & 3 & 3 & 3 & 3 & 4 & 4 & 9 & 11 & 4 & 3 & 7 \\
\hline Foreign currency deposits & 17 & 16 & 15 & 37 & 49 & 54 & 44 & 45 & 45 & 37 & 33 & 21 & 49 & 40 \\
\hline Mac & & & & & & & & & & & & & & \\
\hline Real GDP growth & 3.1 & 3.0 & 3.0 & 3.8 & 1.8 & 8.9 & 4.0 & 6.7 & 5.0 & 6.0 & 7.9 & 3.2 & 4.9 & 6.4 \\
\hline Average inflation & 65.3 & 123.6 & 117.6 & 101.3 & 115.5 & 68.4 & 132.8 & 46.7 & 17.1 & 16.0 & 9.8 & 101.9 & 9105.6 & 22.4 \\
\hline End-of-period inflation & 89.0 & 97.8 & 150.3 & 118.6 & 105.6 & 70.8 & 114.3 & 32.0 & 7.9 & 17.0 & 8.5 & 113.9 & $9 \quad 96.9$ & 16.4 \\
\hline Velocity & 4.2 & 4.0 & 4.2 & 5.2 & 5.5 & 8.3 & 10.4 & 11.6 & 10.7 & 10.3 & 10.3 & 4.4 & 8.1 & 10.7 \\
\hline Fiscal deficit (in percent of GDP) & -2.6 & -2.1 & -1.9 & -1.7 & -3.2 & -3.4 & -0.8 & -0.7 & -0.7 & -0.9 & -0.3 & -2.1 & -2.5 & -0.7 \\
\hline Current account (in percent of GDP & -13.1 & -12.3 & -10.2 & -11.1 & -7.5 & -8.6 & -8.3 & -6.7 & -9.9 & -0.3 & 3.2 & -11.7 & -8.1 & -3.4 \\
\hline Nominal exchange rate depreciation & 98.0 & 277.8 & 297.5 & 60.9 & 84.0 & 109.5 & 74.2 & 17.9 & 37.6 & 8.4 & 0.1 & 183.5 & $5 \quad 89.2$ & 16.0 \\
\hline
\end{tabular}




\section{B. Financial Liberalization and Deepening}

Sporadic attempts to reform the financial system were undertaken in the mid-1990s, but the progress achieved in different areas of the financial reforms has been uneven. Broadly put, the reform attempts in 1990-96 were in line with the efforts to stabilize the economy, cut inflation, and accelerate growth. While major advances are obvious in the liberalization of the financial system and the introduction of the new instruments of indirect monetary control, progress in institutional reforms has been less pronounced. For example, the BOS abolished the individual bank credit ceiling in 1993; tightened conditions for extending lending to nonbanks; and introduced requirements for internal bank control, loan classification and provisioning, and capital adequacy. Although the Financial Institutions Administration was established with the goal of supervising the introduction of new prudential standards, implementation was weak and enforcement widely lacking.

Since 1997 , the BOS has gradually dismantled restrictions and liberalized the financial system (Figure 1). Only after 1997, with the first IMF Staff Monitored Program (SMP), did financial sector reform get an additional impetus. In practically all directions-in financial liberalization, the enhancement of bank supervision and prudential regulation, the introduction of market monetary policy instruments, the promotion of interbank markets, and in institutional reforms-there has been steady progress since 1997. In 1998, the BOS introduced Central Bank Musharaka Certificates (CMCs) and eliminated long-standing, costfree loan facilities to banks and public enterprises, regional floors on credit allocation, requirements for prior BOS approval for large loans, and minimum customers' share under the Musharaka contracts. ${ }^{2}$ In 1999, the BOS established a program to monitor nonperforming loans, approved new rules on credit concentration and lending in foreign currency, and took steps toward reconciling interbank accounts. Finally, in 2000, the BOS further streamlined its lending procedures and embarked on an ambitious program of restructuring and reforming of the banking system.

\section{Since 1998, the BOS has been taking steps to encourage interbank activities and} lending. Although still rudimentary, the interbank market is gradually taking off, with some, mainly private, banks approaching each other, rather than the BOS, in search of a scarce liquidity. This change has been influenced by positive developments in the markets for foreign exchange and government securities. Some banks are engaged in interbank trading in CMCs and placing interbank loans, although such incidents are extremely rare, since they are considered by market participants as evidence of weakness in the bank's position. There is no interbank market in GMCs. In early 2000, the BOS undertook a number of additional steps to encourage nonbank foreign exchange dealers and to develop a system of market makers in

\footnotetext{
${ }^{2}$ See Appendix I for the definitions of Islamic financial instruments used in Sudan.
} 
Figure 1. Sequencing of Financial Reforms, 1990-2000

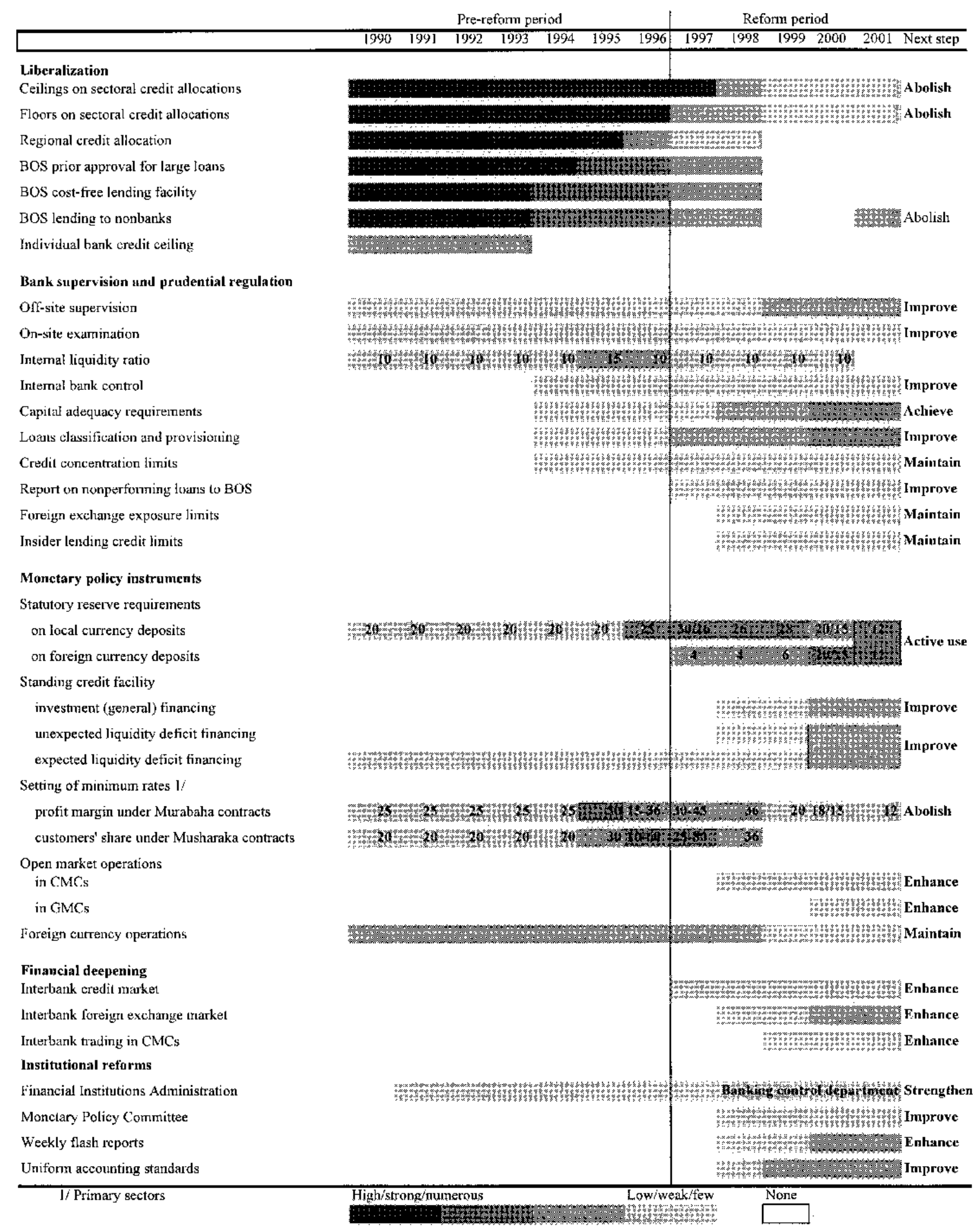


foreign exchange and government securities. The BOS continues to set the minimum profit margin under the Murabaha contracts, but this floor is not binding, as all actual lending incurs higher profit margins. After a number of relaxations, a binding 15 percent ceiling applied on credit to domestic trade was abolished at end-2000, as an indicative. Lending in foreign currency, which is relatively limited, remains under tight BOS control, mainly for prudential reasons.

Substantial progress has been achieved in institution building and monetary policy decision-making. With a view to strengthening monetary management and analysis, in early 1998 the BOS established a Monetary Policy Committee, a key steering body for day-to-day management of monetary policy. The BOS also developed a short-term information system to monitor key items of the balance sheet on a weekly basis. The introduction of weekly flash reports and fact sheets enhanced the quality of decision-making and market transparency of monetary policy. With the help of the Accounting and Auditing Organizations for Islamic Financial Institutions (AAOIFI) in 1998, the BOS introduced uniform accounting principles for all banks and financial institutions. In early 2000 , Khartoum-based branches of the BOS and major commercial banks have been linked through a computer network, which reduced payment float. The BOS also provided a gateway, allowing local banks to join the SWIFT.

\section{Bank Supervision and Prudential Regulations}

The BOS has undertaken a number of steps to improve bank supervision, although progress has been uneven (Attachment 2). Compliance with capital adequacy requirements improved, but by end-1999, 10 banks still did not meet the requirement, compared with 13 banks at end-1996, and some of the banks reported negative capital adequacy ratios. The asset quality of banks has been hampered by a high level of nonperforming loans (about 18-19 percent of total credit in 1998-99); although improved recently, assets still remain below the requirements for a sound banking system. Banks' reporting systems have been upgraded considerably, but analysis of the data collected and follow-up procedures remain weak. The BOS has set foreign exchange exposure limits and introduced a number of institutional changes aimed at reinforcing bank supervision.

Full compliance with capital adequacy standards still needs to be achieved (Table 2.1). According to the 1994 banking reform plan, the BOS required that, by 1997 all Sudanese banks comply with the 8 percent risk-weighted capital requirement. Because compliance was not enforced at that time, in 1999 the BOS revised assets-weighted risk scales and introduced a number of penalties to prompt all banks to comply with the requirement. Under the bank restructuring program, the BOS encourages undercapitalized banks to merge into larger banking entities and, by end-September 2000, to form merger groups through voluntary bilateral contracts. By end-2000, banks within each group are expected to develop merger schedules and appoint appropriate financial advisors. All mergers should be completed by end-November 2001. Alternatively, banks can increase their capital individually to the minimum paid-in capital of SD 3 billion set by BOS (about US\$11 million). The banks are requested to increase their capital gradually- Lo SD 1 billion by end-2000, to SD 2 billion by end-2001, and to SD 3 billion by end -2002 . 
Table 2. Sudan: Prudential Ratios and Limits

\begin{tabular}{|c|c|c|c|c|c|c|c|c|}
\hline \multicolumn{9}{|c|}{$\begin{array}{l}\text { 1. Capital adequacy } \\
\text { (SD billions) }\end{array}$} \\
\hline & \multicolumn{4}{|c|}{ Dec-96 Dec-97 Dec-98 Mar-99 } & un-99 & Dec-99 & Mar-00 & Jun-00 \\
\hline Net capital & 3.0 & 5.5 & 7.7 & 8.5 & 7.3 & 6.0 & 6.5 & 7.0 \\
\hline Risk-weighted assets & 53.6 & 75.3 & 85.8 & 84.7 & 80.9 & 100.6 & 121.7 & 140.0 \\
\hline Capital adequacy ratio (in percent & 5.6 & 7.2 & 9.0 & 10.0 & 9.0 & 6.0 & 5.3 & 5.0 \\
\hline
\end{tabular}

\section{Nonperforming loans}

(SD billions)

Dec-98 Mar-99 Jun-99 Dec-99 Mar-00 Jun-00

$\begin{array}{|lrrrrrr|}\text { Total loans } & 44.3 & 46.4 & 49.8 & 43.6 & 41.3 & 38.0 \\ \text { Nonperforming loans } & 6.9 & 7.7 & 8.4 & 7.8 & 7.7 & 7.6 \\ \text { In percent of total loans } & 15.6 & 16.5 & 16.9 & 17.9 & 18.5 & 20.0\end{array}$

\section{Capital adequacy by number of banks}

\begin{tabular}{|lrr|}
\hline & $\begin{array}{r}\text { Number } \\
\text { Precent of banks }\end{array}$ \\
\hline Well capitalized & Over 15 & 5 \\
Adequately capitalized & $8-15$ & 9 \\
Undercapitalized & $4-8$ & 5 \\
Significantly undercapitalize & $2-4$ & 2 \\
Critically undercapitalized & under 2 & 3 \\
& & \\
\hline
\end{tabular}

\section{Compliance with Prudential Requirements}

(as of March 31, 2000)

\begin{tabular}{|llrr|}
\hline & Limits and ratios & \multicolumn{2}{c|}{ Number of banks } \\
\cline { 3 - 4 } & & 3 & 22 \\
\hline Nonperforming loans & $>6$ percent & 23 & 3 \\
Single lending limit & $>25$ percent & 25 & 0 \\
Insider lending limits & $>10$ percent of capita & 16 & 9 \\
Capital adequacy ratio & $<8$ percent & 14 & 11 \\
Internal liquidity ratio & $<10$ percent & 11 & 14 \\
Provisions/nonpreforming loans & $<30$ percent & 24 & 1 \\
Reserve requirements & $<15$ percent & 11 & 14 \\
Fixed assets+investment/capital+reserves & 6 & 19 \\
Expenses/revenue & $<55$ percent & & \\
& & 133 & 93 \\
Total numbers of cases of compliance/noncompliances & & \\
\hline
\end{tabular}

Source: Bank of Sudan. 
The BOS also improved the existing loan classification system and enforced monthly reporting on nonperforming loans to BOS and the banks' Board of Directors. Since mid-1999, the level of nonperforming loans decreased by 7 percent, although their share in the total loans outstanding has hovered around 18-19 percent because of the decline in overall credit activity (Table 2.2). This is a very high level, comparable to the crisis periods in other developing countries, while in developed countries, the level of nonperforming loans has never exceeded 8-10 percent, even during the worst banking crisis. The high level of nonperforming loans in Sudan reflects the weaknesses of the banking system, as well as a tight definition of such loans adopted by BOS, whereby all loans overdue by one month are automatically classified as nonperforming.

Since 1999, the BOS has pursued a tight policy in dealing with nonperforming loans, which includes moral suasion, possible establishment of a debt management agency (DMA), and imposing penalties on noncompliant banks. If bad debts do not exceed 10 percent of a bank's loan portfolio, the BOS encourages the management (by way of a personal letter) to take corrective measures. If such debts exceed 10 percent, the BOS requests that the bank prepare a debt recovery plan, which is subject to approval by either the deputy governor or governor. While the future of the DMA is uncertain, the idea is that it could purchase from banks assets used as collateral for bad loans, sell them, and use the proceeds to clear the bad debts. The DMA can also acquire and sell shares of indebted companies, equivalent to the value of their bad debt, and take over management of such companies. If actions are not taken by banks within a month after the approval of the debt recovery plans, the BOS can prohibit the noncompliant bank from using its financial windows and from opening new branches; it can impose other penalties as well.

Since 1998, the BOS has introduced a number of new prudential regulations aimed at improving bank soundness. These regulations include limits on banks' foreign exchange exposure and on credit to insiders, mainly to the members of banks' board of directors. BOS also revised the weighted assets risk scales for some Islamic modes of financing, such as Salem and purchasing of goods by banks for commercial purposes to better reflect the specific risks facing banks. The BOS also issued guidelines for Murabaha transactions and intends to issue guidelines for all Islamic modes of finance. It has also started conducting regular reviews of banks' compliance with prudential norms and has established a list of returns the banks must submit on a daily, weekly, monthly, quarterly, and annual basis.

\section{Monetary Policy Instruments}

Until the mid-1990s, the pool of available monetary policy instruments was limited. Historically, the BOS set statutory reserve requirements on deposits in local currency; used a liquidity financing window, which functioned both as an overdraft and lender-of-last-resort facility; fixed minimum profit margins on Murabaha contracts and minimum customers' share under the Musharaka contracts; and conducted foreign currency operations as a tool to control liquidity. 
Since 1997, the BOS has introduced new instruments of indirect monetary management and has modified existing instruments. As part of its effort to widen the pool of instruments to manage liquidity, the BOS introduced a 4 percent reserve requirement on foreign currency deposits in 1997. This parallels the existing reserve requirements on local currency deposits, which were reduced from 30 to 26 percent. In 1998, the BOS opened a financing window with uniform rules of access, which simultaneously served as general financing, lender-of-last resort, and overdraft purposes. In the same year, the BOS unified and reduced the minimum profit margins under the Murabaha contracts from a range of 35-45 percent to 30 percent, and the customer's share under the Musharaka contracts from a range of 30-80 percent to a uniform 36 percent. In 1999, the BOS further reduced the minimum profit margin to fewer than 20 percent, and later to 18 and 15 percent. In 2000, the BOS initially reduced and later unified reserve requirements at a 15-percent level.

The potential of the existing monetary policy instruments still needs to be fully utilized. The existing set of monetary policy instruments is broadly sufficient for efficient monetary control at the current stage of economic development in Sudan, if their potential is fully utilized. Currently, the BOS uses reserve requirements, open market operations (OMO) in $\mathrm{CMCs}$, two financing windows, and the setting of a minimum Murabaha rate as the primary tools of monetary management (Appendix 2). Traditionally, reserve requirements have been used mainly as an instrument of prudential regulation, and, until 2000, they were adjusted only annually. In 2000 , the BOS took a more proactive position and changed reserve requirements twice in response to liquidity conditions in the economy. OMO in $\mathrm{CMCs}$ are at the incipient stage. Although seen by banks as an efficient tool of managing their excess reserves, the impact of CMCs on smoothing the overall fluctuations in such reserves is minimal because of the small size of the $\mathrm{CMC}$ pool. Credit auctioning through the investment financial window is still not active, while very few banks resort to financing from the liquidity deficit-financing window. Finally, the gradual reduction of the minimum Murabaha rate has been used by the BOS as a mere indication of its intentions regarding the rates of charge in the economy, and to signal to banks the desirability of reducing their lending rates.

\section{Preliminary Results of Reforms}

\section{A. Impact on Level of Financial Intermediation}

Reforms have had a widely positive impact on the Sudanese financial system, but this impact has been somewhat different from that of other countries. The trend of growing velocity has been reversed. Main monetary aggregates and deposits started rising in real terms. With the decline in inflation, real rates of return became positive, which stimulated growth in private sector deposits with commercial banks. Finally, the BOS moved toward shifting the priorities of monetary policy from financing government deficits to price stability. However, the financial system remains weak, and so far, reforms have not had a noticeable impact on financial intermediation. The impact of financial reform on credit trends and cost of borrowing in Sudan has been different from that prevailing in most other 
countries. In most countries, in the first years of reform, growth of credit to the private sector exceeded the growth of the deposit base, giving rise to prudential concerns. In Sudan, against the background of healthy growth in the deposit base, credit to the private sector is nevertheless declining in real terms, which may be an impediment to growth. In most other countries, the cost of borrowing increased in the early reform years; it is declining in Sudan.

The process of financial desintermediation of earlier years has been stopped and reversed to a limited extent (Figures 2.1-2.3). All main indicators of financial intermediation-inverse velocity, domestic credit, and deposits--have been steadily declining as ratio to GDP before 1997. For example, the share of broad money to GDP declined from 25 to 9 percent, gross domestic credit from 30 to 7 percent, and total deposits from 14 to 6 percent. This meant growing financial desintermediation of the economy, with the banking system's role reduced to being a paying agent for the government. Through financial reforms, and with government cooperation, the BOS has halted-although not yet reversed - the desintermediation process. Although some indicators picked up slightly in recent years, most of them remain lower than in most other developing countries. For instance, the ratio of broad money to GDP is about 10 percent in Sudan, compared with 30 to 40 percent in Pakistan, Kenya and Tanzania, and 50 to 90 percent in the Cooperation Council for the Arab States of the Gulf (GCC) countries (Jbili et al, 1998).

\section{Regardless of the progress achieved, the overall level of financial intermediation} remains low, and the banking system is still weak and largely undercapitalized. This reflects a combination of economic and social factors. Economic factors include years of financial instability, galloping inflation, rapid nominal exchange rate depreciation, weak financial infrastructure, excessive centralization of economic power within the government, and widespread poverty. Social factors include the vast geographical size of Sudan (the largest country in Africa), poor infrastructure and communications, political instability, and religious constraints. Initial paid-in capital of many banks has been eroded by high inflation in the mid-1990s. In early 2000, out of 26 local banks, 10 (40 percent) were undercapitalized (Table 2.3). Compliance with key prudential requirements still needs to be improved (Table 2.4). 
Figure 2. Sudan: Level of Financial Intermediation,1990-99

\section{Monetary Aggregates}

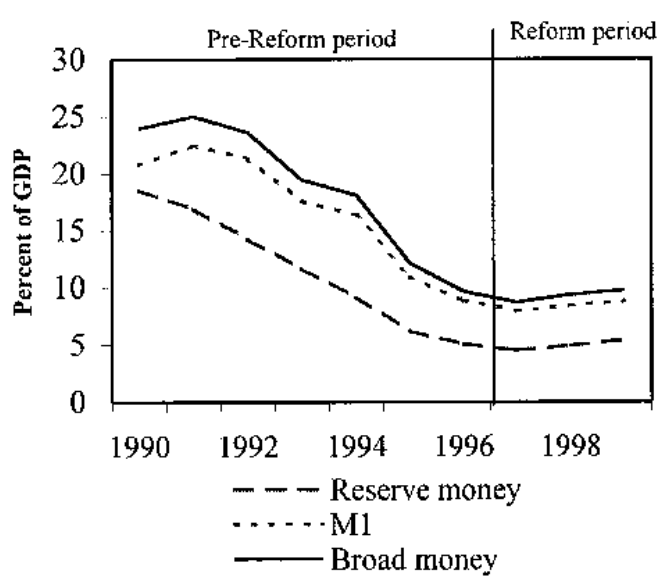

\section{Domestic Credit}

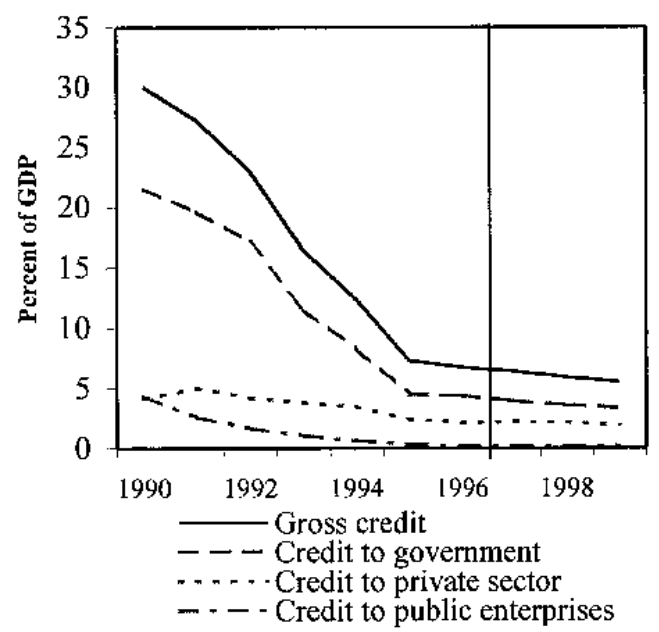

3. Deposits

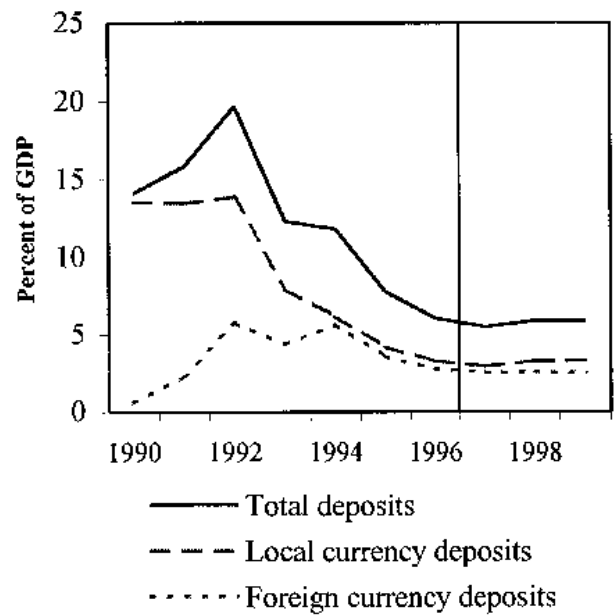

Source: Bank of Sudan, and Fund staff estimates.
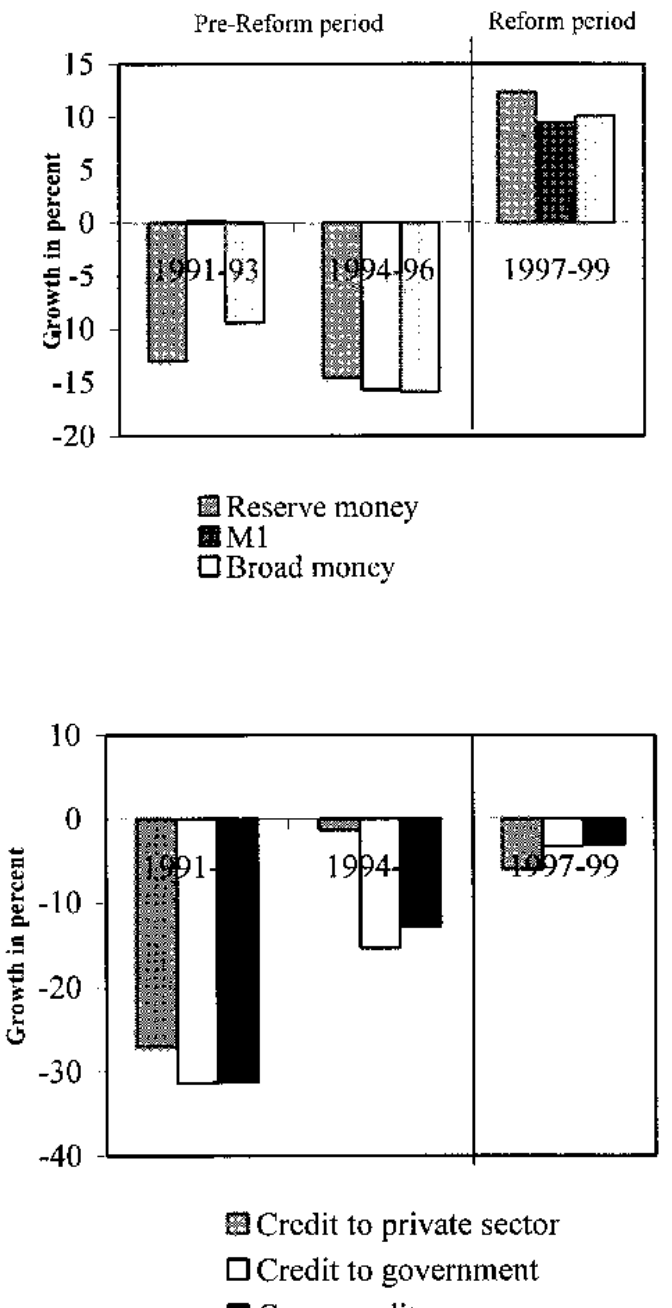

Gross credit

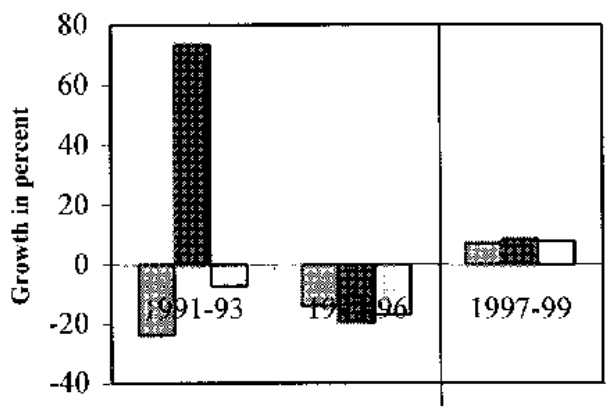

Q Local currency deposits

Foreign currency deposits

$\square$ Total deposits 


\section{B. Impact on Sources of Funds}

Of four main sources of funds-deposits, own capital, public funds, and foreign loansprivate sector deposits were the dominant source of funds for commercial banks in the 1990s (Figure 3.1). About 80 percent of all loanable funds was represented by private sector deposits (both demand and quasi-money deposits), and their share in the total loanable funds remained constant. With the worsening of financial conditions, by the mid-1990s, the share of foreign loans had shrunk, and banks tried to offset the loss of external lines of credit by resolving to additional loans, using their capital. With the exception of 1999 , when the government built its deposits with the banking system, public funds (both BOS credit and government deposits) have never been a significant source of funds for commercial banks. With its predominant share in the sources of funds, the increase in deposits contributed the most to the 8.4 average real growth of the loanable funds in 1997-99, compared with a comparable decline during the pre-reform period of 1991-96 (Figure 3.2).

In spite of some growth in real terms, the deposit base, own capital, and total assets of the Sudanese banks remain small, even by the modest standards of Islamic banks in other countries. ${ }^{3}$ The total amount of deposits in the banking system has been hovering around US $\$ 500$ million since mid-1990, which is one-tenth of the deposits of the single largest Islamic banks (such as the Al Rajhi Banking and Investment Corporation and the Faisal Islamic Banks of Egypt). As about 80 percent of Islamic banks have total deposits in the range of US\$50-500 million, the Sudanese banks are clearly very small by international standards. The average capital of Sudanese banks stood at about US $\$ 3.5$ million during the $1990 \mathrm{~s}$, while about 85 percent of Islamic banks had capital of US\$5-50 million. Total assets of an average Sudanese bank amounts to just US $\$ 24$ million, while 80 percent of Islamic banks have assets of US $\$ 50-500$ million. Thus, by international standards applicable to Islamic banks, Sudanese banks are extremely small. Moreover, although there appears to be a positive correlation between growth of deposits and of capital, financial reform has not yet had any visibly positive impact on the banks' capital base and total assets.

In Sudan, the unremunerated demand deposits dominate the deposit structure, with a share of over 70 percent in mid-2000 (Figure 3.3). This largely reflects the cash nature of the Sudanese economy, where bank customers prefer to have quick and unconditional access to their funds. The demand deposits include checking and current (sight) accounts, which in most cases, cannot be used by banks for loans without prior authorization from the accountholders. Investment and saving deposits, which banks can use at their discretion for extending loans, remain relatively small. In this respect, the Sudanese banks contrast sharply with the deposit structure of most Islamic banks in other countries, where demand deposits constitute at most $7-8$ percent, with a bulk of total deposits represented by investment deposits. Still, since 1997, there has been a visible trend in real growth of investment deposits, contributing substantially to the overall deposit growth (Figure 3.4).

${ }^{3}$ All comparisons are based on Aussaf (1997). 
Figure 3. Sudan: Sources of Financing, 1990-99

(In percent)

1. Sources of Funds

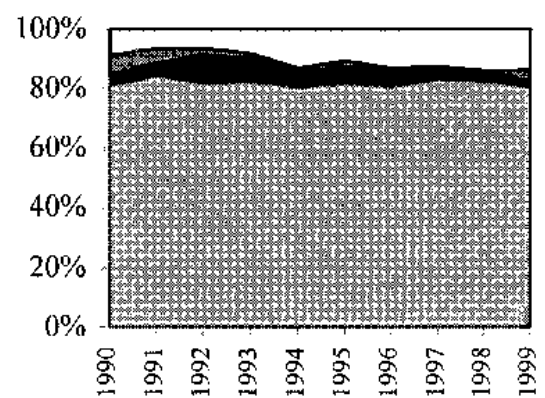

Deposits Foreign !oans Public funds DOwn capital

3. Types of Deposits

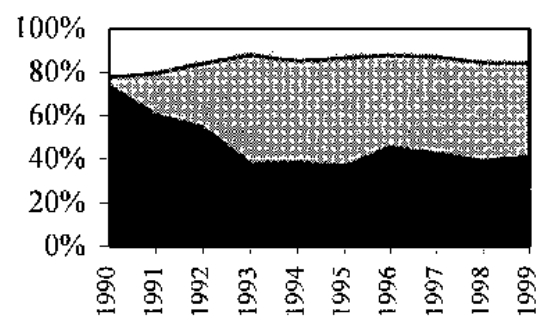

$\square$ Investment and saving deposits

Demand deposits in forcign currency

- Demand deposits in local currency

5. Credit to private sector to deposits ratios

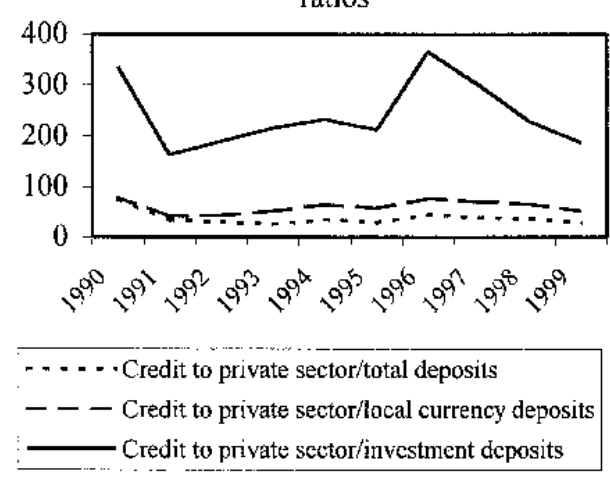

2. Contribution to real growth of the sources of funds

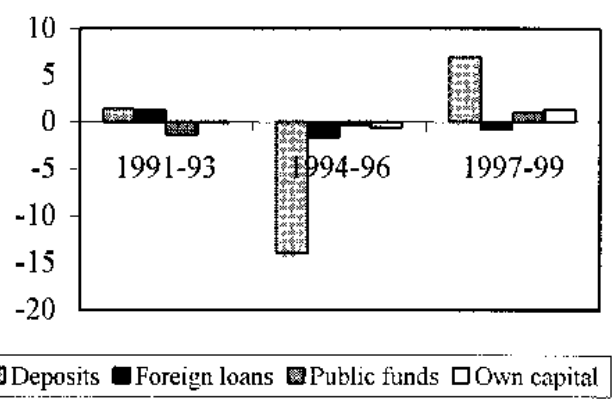

4. Contribution to deposit growth

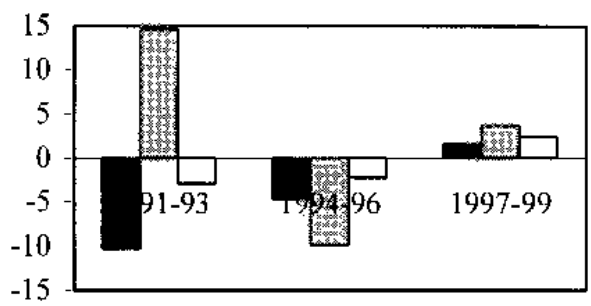

Demand deposits in Incal currency 国 Demand deposits in foreign currency $\square$ Investment and saving deposits

6. Average credit to private sector to deposits ratios

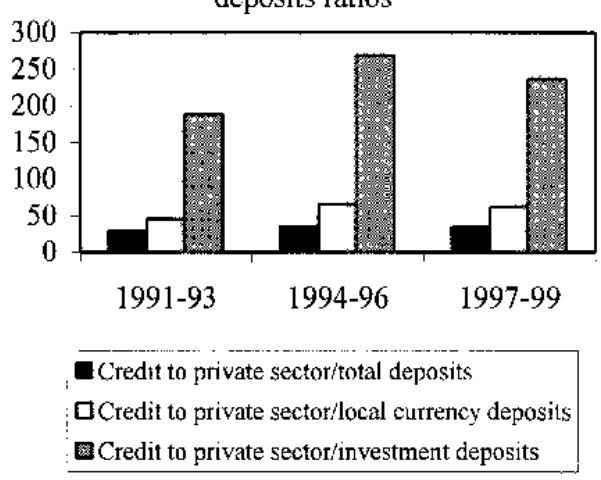

Sourcc: Bank of Sudan, and Fund staff estimates. 
Demand deposits in foreign currency have been rising in real terms through 1998, but in 1999 the trend was reversed, suggesting improved confidence in the local banking system.

Although the ratio of total credit extended by Sudanese banks to the private sector to their total deposits of about 30-35 percent is within the prudent limits, it reflects mainly low credit activity rather than a strong deposit base (Figure 3.5 ). However, excluding foreign currency deposits, this ratio increased during 1990, from 45 percent to over 60 percent, which may be excessively risky, given the higher volatility of foreign cxchange deposits and the weaknesses of the Sudanese financial system. Moreover, the ratio, if calculated, based on investment deposits, is only over 200 percent, clearly suggesting that most banks use a sizable part of demand deposits for extending credits (Figure 3.6). So far, reforms have not improved the term-structure of deposits, most of which remain short-term.

\section{Impact on Credit to Private Sector}

Credit to the private sector contracted in 1993-99 in real terms, and in 1999, even in nominal terms (Figure 4.1). While demand for credit from the private sector has been reportedly high during the $1990 \mathrm{~s}$, credit to the private sector was shrinking annually by 16 percent in 1991-93, by 1.5 percent in 1994-96, and by 6 percent in 1997-99. In total, real credit to the private sector declined by 23 percent since 1993, which particularly affected construction (69 percent), agriculture ( 39 percent decline), mining, and domestic and foreign trade, with credit only to minor sectors, such as transport and storage, services, and staff loans having registered some real growth.

Regardless of the economic reforms, both 1999 and 2000 were by far the worst years for credit to the private sector during the whole decade. In nominal terms, outstanding claims on the private sector in 1999 declined by SD 750 million, with the largest contraction coming from agriculture (SD 2.2 billion) and industry (SD 1.8 billion), representing together about 30 percent of total credit outstanding (Figure 4.2). In real terms, credit contracted by 16 percent, in particular to industry ( 32 percent), agriculture ( 28 percent), and construction (21 percent). Such a decline in credit to the private sector reflects both healthy trends and the inherent deficiencies of the Sudanese financial sector. With the exception of some seasonal increases, associated mainly with trade finance, credit to the private sector remained broadly stagnant in 2000, which forced the BOS to provide emergency bridge financing for agricultural schemes from its own resources.

To some extent, the decline should have been expected, since in the past the value of credit was overblown by centralized allocation of government financing and growing nonperforming loans. Current lower credit is a result of better risk assessment and improved vigilance by commercial banks, as well as of tighter BOS prudential policy. The BOS encourages banks to take a closer look at the quality of their credit portfolio and to assume full responsibility for the recovery of nonperforming loans. Credit decline is also a sign of better and more efficient intersectoral allocation of financial resources after the BOS removed numerous floors and ceilings on credit for particular sectors, which had guided credit allocation in the mid-1990s. Moreover, the BOS promotes commercialization of 
Figure 4. Sudan: Credit to Private Sector, 1990-99 (In percent)

1. Decline (-) or growth $(+)$ of Real Credit to Private Sector, 1993-99 ${ }^{1 /}$

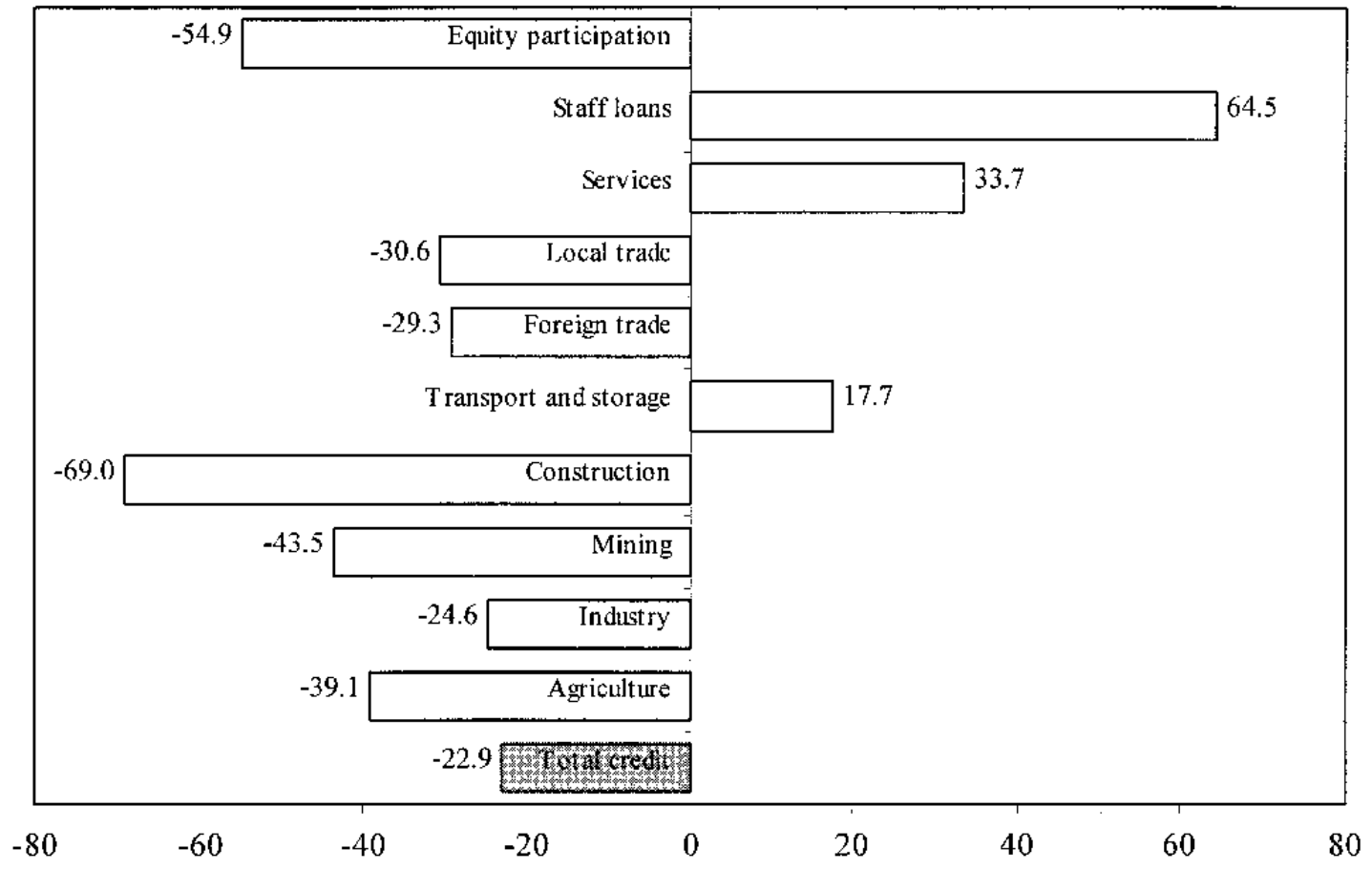

2. Decline (-) or growth (+) of Real Credit to Private Sector in $1999^{1 /}$

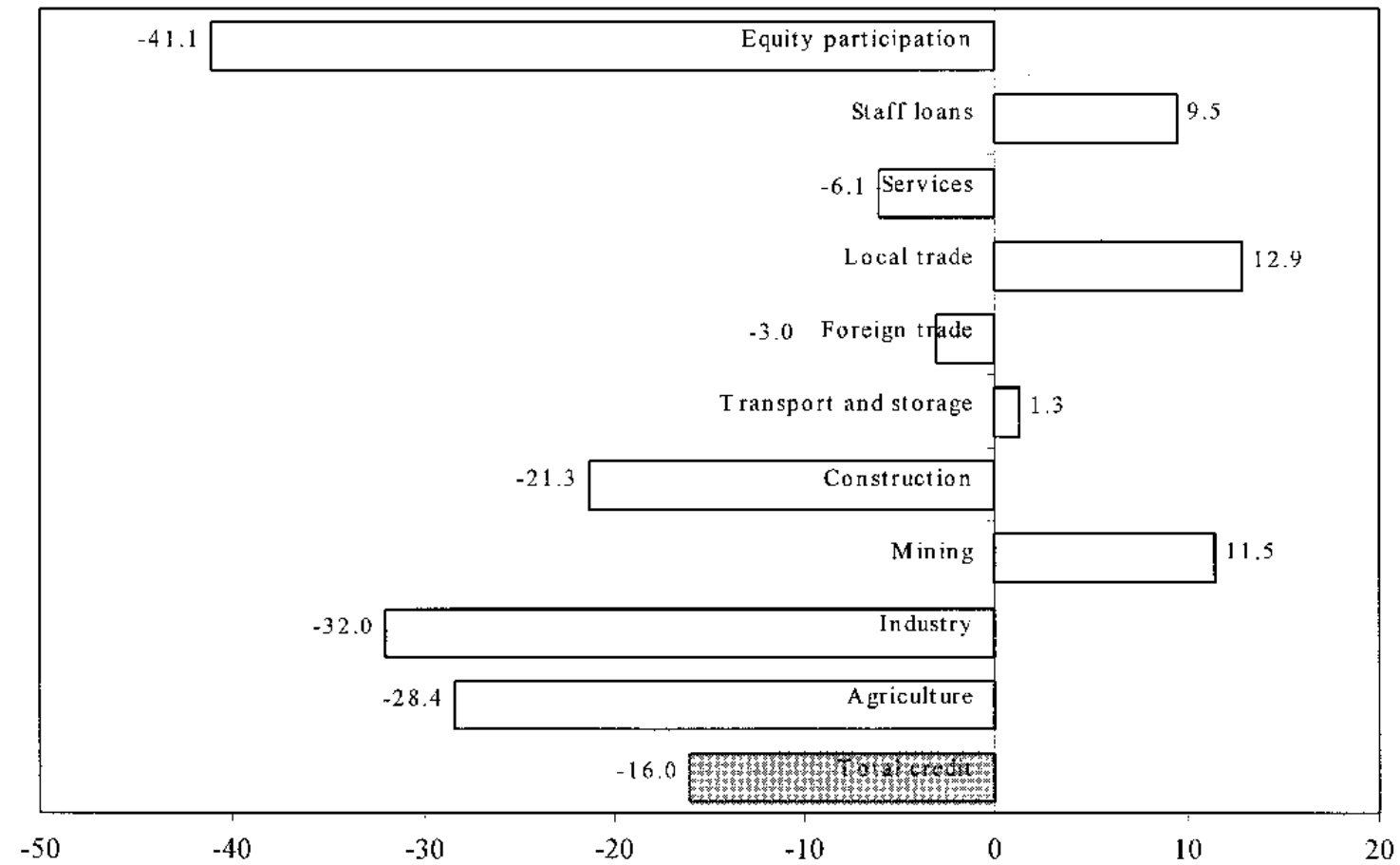

Source: Bank of Sudan

${ }^{1 /}$ Deflated by CPI. 
former specialized banks, such as the Agricultural Bank, which was a vehicle of centralized, and in most cases, unrecoverable, financing. Thus, declining in real terms, credit activity is looking for its real value, consistent with the current level of economic development in Sudan.

The decline in credit to the private sector may reflect the prolonged deficiencies of the Sudanese financial system, which still needs to be addressed in the process of financial reforms (Box 2). These deficiencies reflect the deep-rooted problems of the Sudanese economy-it remains heavily skewed toward agriculture, with immature industrial and service sectors, confidence in banks is remarkably low, and external financing is virtually nonexistent. The decline in credit was also due to the inefficiency of the banking business itself (high costs, absence of risk-hedging instruments, excessive BOS involvement), its structural inadequacies (lack of mechanisms for agricultural financing, outdated financial laws, design shortcomings in consortium financing), as well as the need to observe religious rules unavoidable under the Shari'a.

As a result, the Sudanese banks prefer accumulating excess reserves rather than lending to the private sector. By end-2000, banks' excess reserves maintained at the BOS reached one half of their outstanding credit. The ratio of reserves to deposits jumped from 23 percent in September 1999 to 32 percent in September 2000 and led to a decrease of 10 percent in the multiplier over the same period. The fact that banks accumulate reserves rather than lending to the private sector is obviously related to the structural problems of the banking system, with most banks undercapitalized, fragmented, and of low profitability. An important factor behind the poor profitability is the very high staff and administration costs of the banks (averaging 9 percent of total assets and reaching 20 percent in some banks), which is also a driving cause of the high costs of lending in Sudan. In addition, the high level of excess reserves poses challenges for the monetary policy, as indirect monetary policy becomes less effective, and the BOS has to deal with the difficult task of neutralizing potential inflationary pressures stemming from the excess reserves, while encouraging banks to lend to the private sector.

The BOS is taking active measures to address the problem of credit decline. Within a broader framework of bank restructuring, key measures include: encouragement of amalgamation of banks through recapitalization, mergers, or liquidation; modification of banking and other financial laws to allow for greater flexibility in bank registration and liquidation; and collection of nonperforming loans and selling collateral. In addition, the BOS continues its policy of financial liberalization by relaxing further the ceiling of credit for domestic trade, reducing and unifying reserve requirements, and enforcing international standards of prudential regulation and banking supervision. The MOF, through the BOS, provides guarantees to banks participating in the consortium financing agriculture. The BOS, on its side, provides additional liquidity support to the economy by auctioning its credit to banks on a competitive basis. 


\section{Box 2. Sudan: Reasons for the Decline of Real Credit to the Private Sector}

- The capital base of most banks is not sufficient for extending sizable loans. The capital and deposit bases have been eroded by high inflation in mid-1999. Many banks are undercapitalized and do not comply with the 8 percent capital adequacy ratio.

- Banks consider the risk of extending credit to all sectors, other than trade, unjustifiably high. Credit to all other sectors, in particular to agriculture ( 30 percent of total credit), is perceived by all banks as an extremely risky business because about 85 percent of all nonperforming loans originate in agriculture.

- Main borrowers-the agricultural schemes - are experiencing major structural problems. They remain unprofitable with large debts outstanding from previous years and can be restructured only over the medium term.

- The cost of borrowing, although gradually declining, remains high. At end-March 2000, the average Murabaha lending rate stood at 25.6 percent a year ( 9.7 percent in real terms), but could go as high as 34 percent ( 16.7 percent in real terms). The main reasons behind such a high cost of borrowing is the insufficient interbank competition, the large geographical size of the country complicating transactions and transfers, the absence of computerized interbranch networks, and inefficiency of other banking technologies. Most banks extract about 70 percent of their net profit from administrative fees and charges imposed on customers, rather than from pure banking activities.

- Some Islamic modes of financing (Salem, Musharaka) do not seem to be operationally efficient, in particular in financing agriculture. Under Salem, banks often cannot sell in-kind repayments at a price allowing them even to recover the value of the initial credit. Some banks are reluctant to enter in a Musharaka contract with the agricultural producers because this mode of financing requires banks' participation in the management of the financed project, which banks are not always willing to do.

- Specialized banking services are no longer available for the most vulnerable sectors, such as agriculture. All specialized banks - such as the Agricultural Bank, Industrial Banks, Estates Bank and Savings Bankshave been either merged with other commercial banks or have become regular commercial banks and base their activity on profit maximization considerations. Other banks have neither experience nor enough branches all over the country to finance agriculture.

- Consortium type of bank financing for large public projects is not sufficient. While no single bank can finance large agricultural schemes, such as the Gezira, a consortium led by the Bank of Khartoum, even with the participation of the BOS, is not an efficient instrument for arranging contributions from individual banks. Consortium financing is not enough to cover the demand for working capital, while all member banks are reluctant to extend credit for investment needs without a government guarantee.

- High yields on CMCs and GMCs distract potential lenders from private sector financing. In addition, the need to comply with stricter prudential regulations limits banks' desire to finance the private sector.

- Banks virtually have no lines of credit extended from abroad. The few that are available, mainly to join banks, have a very high country risk markup above the Libor (up to 4 percentage points).

- Under the Shari'a, whole sectors of economic activity remain closed for bank financing. In addition to alcohol and tobacco being off-limits for religious reasons, credit for such important private sector fields as hotels, restaurants, and entertainment is also forbidden.

- On the demand side, there still exist some ethical constraints for consumer borrowing. On a personal level, borrowing is perceived as bad and is discouraged under the Shari'a. It is viewed as encouraging a consumerism that contradicts their religious principles of moderation. On the national level, borrowing is seen as destructive because consumer debt leads to a nation of debtors. 


\section{Impact on Efficiency of Monetary Policy}

The impact of monetary policy on the stated targets of the BOS monetary policy-real GDP growth, reduction in inflation, and exchange rate stability-has become more pronounced with the start of financial reforms after 1997. The link between reserve money creation and broad money expansion has been strong during the 1990s (Figure 5.1). In the early $1990 \mathrm{~s}$, the multiplier was moving in a barely predictable manner, thus weakening the transmission mechanism. Since 1996, it has stabilized then declined, while changes in reserve money began to project virtually fully into broad money. The link between broad money and GDP growth has always been much weaker because broad money velocity has been volatile and largely unpredictable (Figure 5.2). It can still be said that with reforms, velocity stabilized and then moved to a slowly decreasing path; this is in comparison with previous large swings, which strengthened the link between broad money and nominal growth. Finally, after disintegrating GDP growth into real growth and inflationary components, it becomes obvious that the BOS monetary policy has had a much more pronounced effect on achieving the ultimate goal of decreasing inflation than of real GDP growth. Price stabilization effect is obvious during the whole reform period, whereas real growth is clearly influenced by additional factors, exogenous to monetary policy.

The efficiency of the monetary policy in Sudan depends critically on the selected exchange rate regime and, as a result, on the extent the $B O S$ can control reserve money. Control over reserve money is critical for the monetary policy to be conducive to achieving long-term growth and inflationary targets. In the medium and long run (within a period of several years), broad money supply in Sudan is closely tied to movements in reserve money. This link becomes obvious if growth rate of nominal stocks of broad money is compared with the corresponding growth rates of each of its components-reserve money and the monetary multiplier. The variability of broad money growth is quite apparent - from over 100 percent a year in the prereform period, to about 30 percent a year after 1997 . Of the two possible reasons for such variability, growth in reserve money is the obvious explanation, while the multiplier fluctuated within much narrower margins. Overall, during 1991-99, broad money growth at over 4,400 percent is explained overwhelmingly by the 3,900 percent growth in reserve money, with a marginal 12 percent contribution from the growth in the multiplier.

In most of 1999 and all of 2000 , the BOS pursued a monetary policy that led to a defacto fixed exchange rate regime and faces a challenge of exchange rate policy choice. By active interventions in the foreign exchange market with a view to maintaining exchange rate stability, the BOS broadly relinquished its long-term control over the monetary policy. With a proactive policy on exchange rate stabilization, the BOS can preserve some shortterm control over reserve money, as long as the exchange rate is in market equilibrium. If the exchange rate is in market equilibrium, BOS operations will be reduced to smoothing shortterm fluctuations of the exchange rate; this will produce short-term shifts in reserve money, in principle sterilizeable with the available monetary policy instruments, and allow some degree of freedom for monetary policy. If, on the contrary, the BOS tries to maintain an exchange rate when the market is out of equilibrium and sells or buys foreign exchange on 
Figure 5. Sudan: Transmission of Monetary Policy, 1990-99

(Nominal growth in percent, 1990 $=100$ )
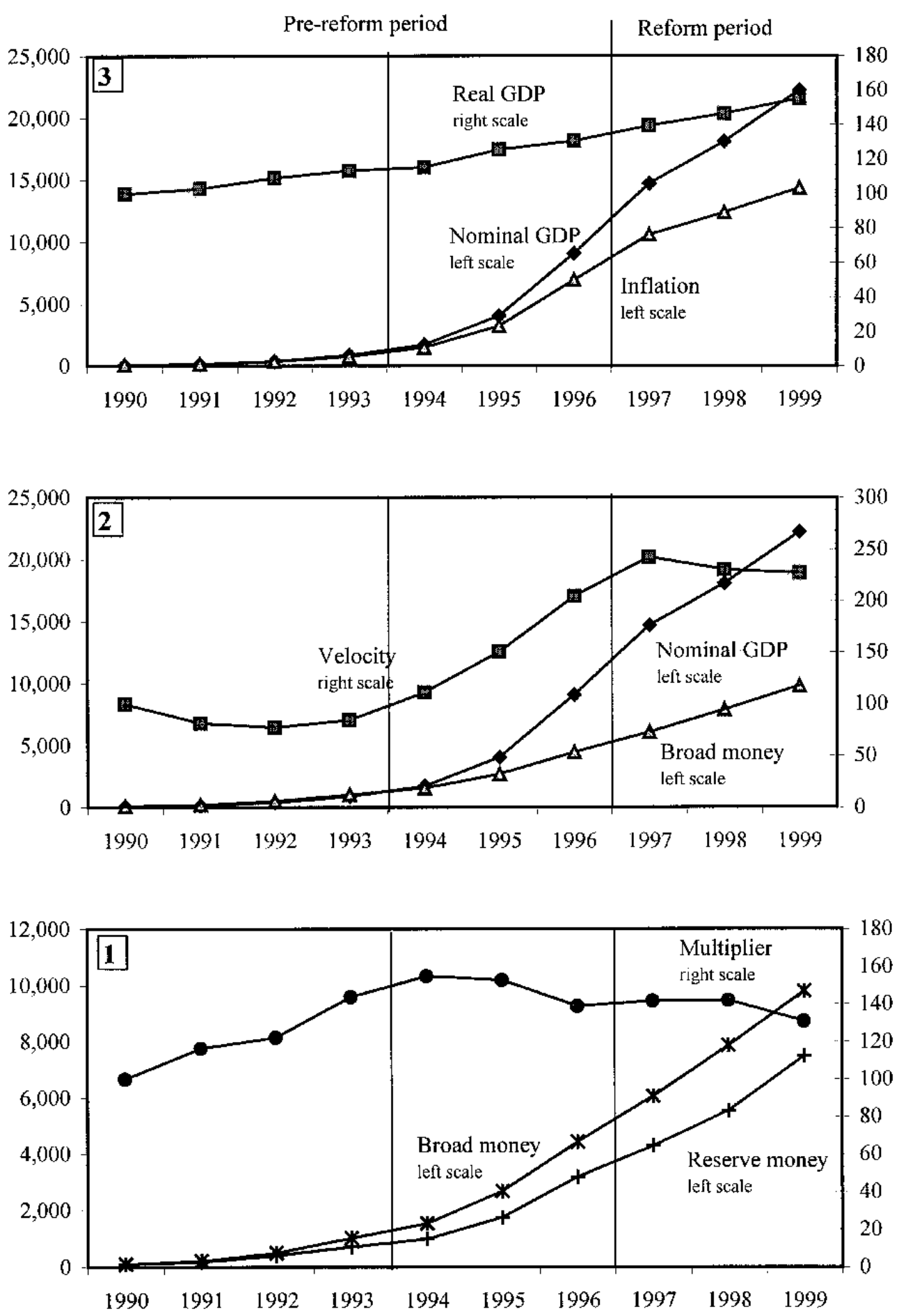

Source: Bank of Sudan, Central Bureau of Statistics, and Fund staff estimates 
demand, thus changing reserve money, it will lose any control over monetary policy. Monetary policy will become broadly inefficient for achieving the ultimate medium- and long-run macroeconomic targets.

The shift to a de-facto fixed exchange rate was premature because it could not be defended efficiently with the existing low level of reserves, and the BOS has broadly lost the benefits of active reserve money management gained in the late 1990s. By end-1999, the BOS could control about one-third of reserve money movements, which represents a significant improvement compared with earlier years (Table 3). In 1991-93, the BOS could control about one-fifth of reserve money movements, mainly by foreign exchange operations. In 1994-96, such operations contributed negatively to BOS control over reserve money, which was broadly lost. Of the six identified supply-side BOS operations affecting reserve money, the BOS has effective control over its credit to commercial banks, credit to public enterprises, and net purchases of CMCs and, with a virtually fixed exchange rate regime, it maintains some control over its accumulation of foreign assets. The contribution of effectively controlled factors was marginal in the performance period, when changes in credit to banks and public enterprises contributed insignificantly to changes in reserve money, because they were overwhelmed by large swings in other components, and CMCs simply did not exist. Owing to reforms, the contribution of the efficiently controlled factors to reserve money increased to 12 percent, mainly reflecting reduction of the relative size of factor beyond BOS control.

Net foreign assets fluctuations (excluding valuation changes), which can be controlled by BOS should the flexible exchange rate be pursued, contributed about one-quarter to reserve money movements in 1997-99. In the case of Sudan with its immense external debt, in the early 1990s net foreign assets reflected the accumulation and repayments of overdue external debt obligations. In the mid-1990s, with no external debt repayments, the BOS continued to accumulate overdue liabilities with no control of their expansion, which had a strong but uncontrolled contractionary effect on reserve money. In late 1990s, reserve money expansion was due mainly to the inflow of foreign capital, which, with targeted accumulation of usable reserves and scheduled repayments to the IMF and other creditors, returned- to some degree - under BOS control. Although with heavy BOS involvement in the foreign exchange market with a view to stabilizing the exchange rate, foreign reserve accumulation above the targeted limits acted inversely and reduced BOS control of reserve money.

Net credit to government has been the largest identifiable source of reserve money fluctuation, controlled jointly by the BOS and Ministry of Finance within the budgeted ceiling. With low-policy independence, the BOS does not have individual, direct control of government borrowing or drawdown of its deposits. This is largely an outcome of the government's fiscal position, and the BOS can use this instrument for purposes of monetary policy only if it has a mutual understanding with, and receives full cooperation from, the government. Thus, monetary policy in Sudan is still basically determined by the borrowing needs of the government, and a more independent policy at the BOS could clearly contribute to a better control of reserve money, while the government's financial needs could be covered by borrowing from the financial market. 
Table 3. Sudan: Degree of BOS Control of Reserve Money Expansion

\begin{tabular}{|c|c|c|c|c|c|c|c|c|}
\hline \multirow[b]{2}{*}{ Period } & \multirow[b]{2}{*}{ Year } & \multicolumn{6}{|c|}{ BOS operations } & \multirow[b]{2}{*}{$\begin{array}{l}\text { Total } \\
\text { inrease in } \\
\text { reserve } \\
\text { money }\end{array}$} \\
\hline & & $\begin{array}{l}\text { purchases of } \\
\text { foreign } \\
\text { assets }^{1 /}\end{array}$ & $\begin{array}{c}\text { Credit to } \\
\text { banks }\end{array}$ & $\begin{array}{l}\text { Credit to } \\
\text { public } \\
\text { enterprises }\end{array}$ & $\begin{array}{c}\text { Net } \\
\text { purchases } \\
\text { or CMCs }\end{array}$ & $\begin{array}{l}\text { Net credit to } \\
\text { government }\end{array}$ & $\begin{array}{c}\text { Other } \\
\text { operations } \\
\text { (net) }\end{array}$ & \\
\hline \multicolumn{9}{|c|}{ (Contribution of main operations in percent) } \\
\hline \multirow[t]{6}{*}{ Pre-teform } & 1991 & 27.1 & 0.0 & -3.0 & 0.0 & 111.3 & -35.4 & 100.0 \\
\hline & 1992 & 15.2 & 0.8 & -0.7 & 0.0 & 109.8 & -25.1 & 100.0 \\
\hline & 1993 & 24.1 & 7.3 & -0.4 & 0.0 & 77.1 & -8.1 & 100,0 \\
\hline & 1994 & -60.5 & -2.8 & 0.0 & 0.0 & 54.4 & 108.8 & 100.0 \\
\hline & 1995 & -13.4 & 0.0 & 0.0 & 0.0 & 60.3 & 53.2 & 100.0 \\
\hline & 1996 & -16.9 & 0.0 & 0.0 & 0.0 & 111.0 & 5.8 & 100.0 \\
\hline \multirow[t]{3}{*}{ Reform } & 1997 & 32.9 & 16.5 & 0.0 & 0.0 & 35.5 & 15.0 & 100.0 \\
\hline & 1998 & 19.9 & 14.7 & 0.0 & -3.8 & 25.6 & 43.6 & 100.0 \\
\hline & 1999 & 16.2 & 2.7 & 8.2 & -2.8 & 32.3 & 43.5 & 100.0 \\
\hline \multirow[t]{3}{*}{ Average contribution } & $1991-93$ & 21.2 & 2.3 & -1.3 & 0.0 & 101.5 & -23.7 & 100.0 \\
\hline & $1994-96$ & -24.3 & -0.6 & 0.0 & 0.0 & 80.0 & 44.9 & 100.0 \\
\hline & $1997-99$ & 23.1 & 11.0 & 2.9 & -2.1 & 31.4 & 33.6 & 100.0 \\
\hline \multicolumn{2}{|l|}{ Degree of BOS control } & Some & High & High & Iligh & Some/None & None & \\
\hline Average contribution & | 1991-93 & 21.2 & & 1.0 & & 77 & & 100.0 \\
\hline to reserve money & $1994-96$ & -24.3 & & -0.6 & & 124 & & 100.0 \\
\hline fluctuations & 1997-99 & 23.1 & & 11.8 & & 65. & & 100.0 \\
\hline
\end{tabular}

Source: Bank of Sudan, and Fund staff estimates.

$1 /$ Excluding valuation changes.

Credit to banks and public enterprises make up most of the sources of reserve money controlled by the BOS. ${ }^{4}$ The amounts and terms of financing from both available financing windows-investment and liquidity financing - are set and controlled by the BOS. However, banks and public enterprises make their own decisions to apply for such loans, regardless of BOS' intentions or the need to affect reserve money. Since the interests of banks and the

${ }^{4}$ Advances to public enterprises include direct credit to Cotton Company, agricultural schemes (Gezira, New Halfa), and old balances of credit to Sudan Currency Printing Corporation, Sudan Shipping Lines, and Gum Arabic Company. 
BOS may not coincide in time and volumes, the efficiency of BOS control of this monetary policy decreases. For example, in early 2000 , one BOS financing auction was suspended because of the lack of demand from commercial banks, and bank participation in other auctions was not particularly active. Moreover, in Sudan, monetary policy has not yet been completely divorced from the political process, and the BOS has, at times, to subordinate its objectives to accommodate government financing needs, such as credit to public enterprises and agriculture.

\section{Open market operations as a tool to control reserve money are in their infancy and} have contributed marginally to fostering BOS control of reserve money. Such operations in CMCs started in 1998 and have been used by the BOS mainly as a tool to smooth shortterm fluctuations in reserve money and to offer banks a return-bearing investment opportunity for their excess reserves. Of two instruments (CMCs and GMCs) available for open market operations, the former is too small to mitigate large fluctuations of liquidity effectively, and the latter was used for the first time during end-2000 to absorb some excess liquidity, but still is not viewed as an efficient policy instrument. Although demand for both instruments has picked up dramatically since their inception, CMCs began to be traded at above face value, close to the fair market value of the underlying assets. All recent auctions for GMCs have been oversubscribed, and the bid price also exceeded their face value.

Large and unpredictable movements in the public sector's deposits with BOS hamper its control of reserve money. Two kinds of public sector deposits dominate public sector deposits - deposits of about 350 government units held at $\mathrm{BOS}^{5}$ and deposits of two large public enterprises (Sudan Petroleum Corporation and Sudan Sugar Corporation). The BOS can predict movement in only about one-third of central government units, which receive funds only from the MOF; all other units are partly self-financed and the movements of their deposits at BOS are highly unpredictable. Under the existing system, fluctuations of deposits of public enterprises, in particular SPC, are completely beyond BOS control. The largest movements in its accounts have been associated with oil imports, when the SPC is required to deposit the full amount of counterpart in local currency in a blocked account with the BOS against a letter of credit opened by the BOS in foreign currency in favor of a foreign oil supplier. Such cash deposits, received and routed through BOS accounts, give rise to an unintentional sterilization of reserve money.

\footnotetext{
${ }^{5}$ These deposits are classified in group 11 (central government), group 12 (semi-government, branch and other branches in local and foreign currency), group 13 (mainly public enterprises, including the Zakat Fund), and group 19 (government-financed projects, including oil accounts). By law, the government must keep all its deposits at the BOS, although some transitional accounts (mainly to pay civil servant salaries) are placed with large commercial banks.
} 


\section{E. Impact on Predictability of the Multiplier}

In the short run (up to three quarters), swings in the monetary multiplier have had a substantial impact on money supply. Unlike most countries, where the behavior of the multiplier is positively synchronized with the changes in reserve money, two periods clearly stand out in recent Sudanese history. In the early 1990s, the multiplier was the factor accelerating money supply, while since 1994, the multiplier has been on a decline, which contributed to the overall slowdown of broad money growth. Monthly swings of the multiplier have been particularly characteristic and pronounced in the mid-1990s, reflecting shifts in demand for cash, stemming from both confidence and seasonal effects, as well as the changes in BOS credit allocation polices. The BOS does not have direct control over all components of the multiplier. Changes in the multiplier reflect: the BOS policy of reserve requirements affecting the volume of reserve money and the multiplier through the reserve/deposit ratio; depositors' preferences for cash or deposits reflected in currency/deposit ratio; banks' decisions on how much reserve to keep for a given level of deposits, revealed through the excess reserve/deposit ratio; and, indirectly, borrowers' behavior.

With the start of reforms, the multiplier became more stable-although still lowerand more volatile than in a conventional banking system. In the high inflationary environment of the prereform period, the multiplier increased from 1.36 in 1990 to 2.04 in 1995, but declined to 1.72 in 1999 , when inflationary pressure abated (Figure 6.1). The level of the multiplier in the range of 1.5 to 2 is clearly lower, compared with many other developing countries. This is an outcome of higher currency/deposits and reserve/deposit ratios in Sudan. This phenomenon is common for most developing countries with an Islamic financial system. A lower multiplier reflects both the public's preference for cash and relatively high reserve requirements set by the BOS, as well as lower time/demand deposits and excess reserves/demand deposits ratios because of the preference for highly liquid demand deposits. The 30 percent swings of the multiplier attest to its instability in the first half of the 1990s, although after 1997 its fluctuations decreased and did not exceed 7 percent. While the declining trend of the multiplicr is in line with reduced inflation, it still does not follow that the multiplier is stable enough to allow the BOS to assume it as a given in its policy actions.

Reserve requirements became a useful instrument for controlling the behavior of the multiplier, although its efficiency declined because of high excess reserves. In the prereform period, the movements of the reserve/deposits ratio have been largely divorced from the BOS policy on reserve requirements (Figure 6.2). Trying to curb inflation, the BOS sharply raised the required reserve ratio from 20 percent in the early 1990 s to 30 percent in 1997, and maintained it at a relatively high, but declining, level thereafter. Taking other variables as unchanged, the resulting contraction of banks' loanable reserves was reflected in the increased reserve/deposit ratio. Higher reserve requirements led to a contraction of credit and decelerated deposit creation. This shrank the broad money supply, resulting in a decline of the multiplier during the reform period. To achieve the goals of monetary policy, the BOS could use the reserve requirements even more actively as a relatively efficient policy tool for regulating liquidity. 
Figure 6. Sudan: Money Multiplier Components, 1990-99

(In percent)
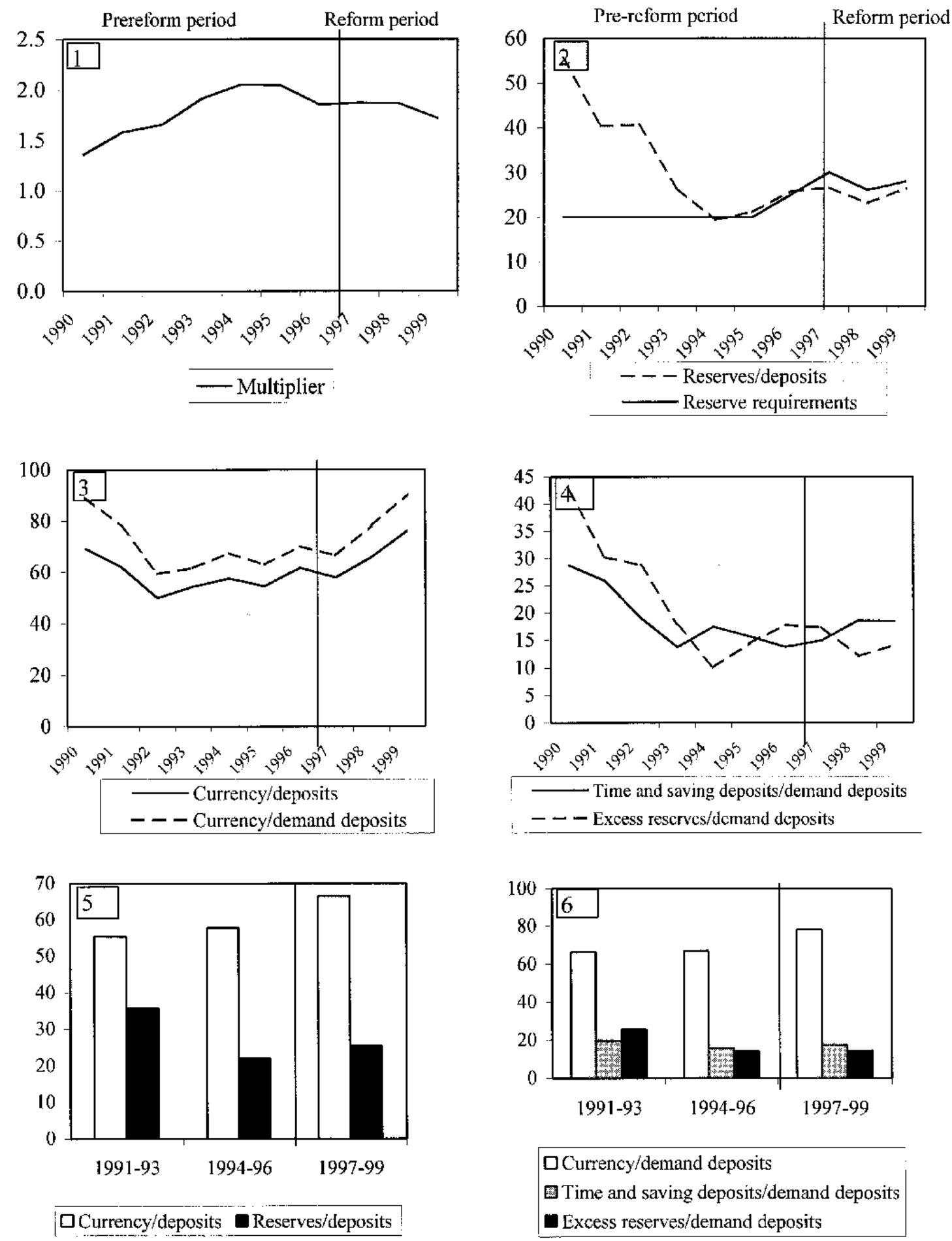

Source: Bank of Sudan and Fund staff estimates. 
Reserve requirements became a useful instrument for controlling the behavior of the multiplier, although its efficiency declined because of high excess reserves. In the prereform period, the movements of the reserve/deposits ratio have been largely divorced from the BOS policy on reserve requirements (Figure 6.2). Trying to curb inflation, the BOS sharply raised the required reserve ratio from 20 percent in the early 1990 s to 30 percent in 1997, and maintained it at a relatively high, but declining, level thereafter. Taking other variables as unchanged, the resulting contraction of banks' loanable reserves was reflected in the increased reserve/deposit ratio. Higher reserve requirements led to a contraction of credit and decelerated deposit creation. This shrank the broad money supply, resulting in a decline of the multiplier during the reform period. To achieve the goals of monetary policy, the BOS could use the reserve requirements even more actively as a relatively efficient policy tool for regulating liquidity.

The behavioral currency/deposit ratio is unstable and fluctuates within a wide margin; it has also been growing, all of which indicate a clear preference for cash and low confidence in the banking system. Stability of this ratio, a key requirement for predictability of the multiplier, is not satisfied-the standard deviation of the currency/deposit ratio in the 1990s was 7.8, and that of currency/demand deposit ratio was even higher, about 11. Currency/deposits and currency/demand deposits ratios are very high at around 70-80 percent, compared with 10 percent in GCC countries (Figure 10.3), and they deteriorated during the reform period. Unfavorable evolution of the ratios reflects a combination of factors, such as widespread cash-based transactions, lower opportunity cost of holding currency compared to deposits, weakness, and low confidence in the financial system. The higher level of currency/demand deposits compared with the currency/deposit ratio clearly suggests lower opportunity cost of holding currency compared to demand deposits, which are not remunerated, rather than investment deposits. The deterioration of the ratios may also reflect a negative impact of the initial stage of reforms on individual wealth and a decline in income.

Commercial banks' policy on excess reserves is mainly a reflection of their cautious policy on crediting the private sector. The excess reserves/demand deposit ratio has been in decline through the 1990s (Figure 6.4). Being to some extent controllable by the BOS through reserve requirements, this ratio, nevertheless, mainly reflects the banks' reaction to changes in opportunity cost of holding excess reserves and the banks' assessment of the expected deposit outflow. With inflation in decline since the mid-1990s, and the achievement of a positive rate of return in 1997, the excess reserves/demand deposits ratio declined, suggesting a more active extension of loans by commercial banks. At the same time, the probability of bank runs, and thus large deposit outflows, declined, which also contributed to ratio improvement. After most credit ceilings were removed, the excess reserves/demand deposits ratio became more controllable by $\mathrm{BOS}$ policies on reserve requirements. Characteristically, with the start of financial reforms, associated by many banks with some degree of uncertainty, assessment of the potential deposit outflow has changed again and the excess reserves/deposit ratio increased. 
In the case of Sudan, the multiplier model of money supply encounters obvious limitations. The traditional model assumes stability, or at least a high degree of predictability, of the multiplier. In the case of Sudan, an exogenous to BOS policy factorthe public's selection between cash and deposit_clearly dominates other factors affecting the multiplier. Although BOS impact on the multiplier through the reserve requirements and banks' policy on excess reserves plays a significant role, they are more than offset by the high volatility of the currency/deposit ratio, which cannot be directly controlled by the BOS. Its volatility, in turn, is affected by price level, relative price of consumer versus durable goods, and the implicitly existing interest rate. Thus, the BOS' impact on broad money supply, and ultimately on nominal income, could be more predictable if it targeted the level of banks' reserves through open market operations and adjusting reserve requirements and made it the main operational goal of its monetary policy.

\section{KEY IMPEDIMENTS TO THE SUCCESS OF REFORMS}

\section{A. Sequencing of Reforms}

\section{Earlier and more focused macrostabilization efforts would have been clearly} advantageous for the success of the Sudanese financial reform. World experience suggests (see Fischer and Gelb, 1991) that financial market reforms usually come relatively late in the overall order of reforms, after macroeconomic stabilization has been broadly achieved (Figure 7). In Sudan, consistent efforts toward financial liberalization started in 1997, which was the first year when the average inflation declined to below 100 percent, but the rate of charge remained negative in real terms, and the Sudanese currency was depreciating precipitously. First results of macroeconomic stabilization did not become evident until late 1998. With the significant two-way causation between the soundness of the financial system and macroeconomic stability objectively, in the conditions of continuing macroeconomic imbalances, the authorities could not pursue vigorously financial sector reforms in 1997 and most of 1998. Thus, the position of the financial sector reform in the sequencing of reform has not been entirely adequate - either the stabilization effort should have started earlier or the financial sector reform should have begun after the basic macroeconomic conditions had been put in place.

Sectoral reforms supporting financial reform have not been sufficient. Exchange rate reform (primarily, exchange rate unification and the removal of surrender requirements) usually precedes any significant restructuring of the banking sector. Sporadic and convoluted attempts to unify the exchange rate undertaken in the mid-1990s were not successful because the supporting fiscal and monetary policies had not been put in place. The delays in exchange rate reform have affected the banking sector reform and have not been supportive of it. While the trade reform has been broadly in line with what was needed and has been pursued consistently, other structural reforms and, in particular, legal reform and privatization have been delayed for too long as well. Key reforms of the legislative framework for bank 
Figure 7. Sudan: Stylized Sequencing of Reforms

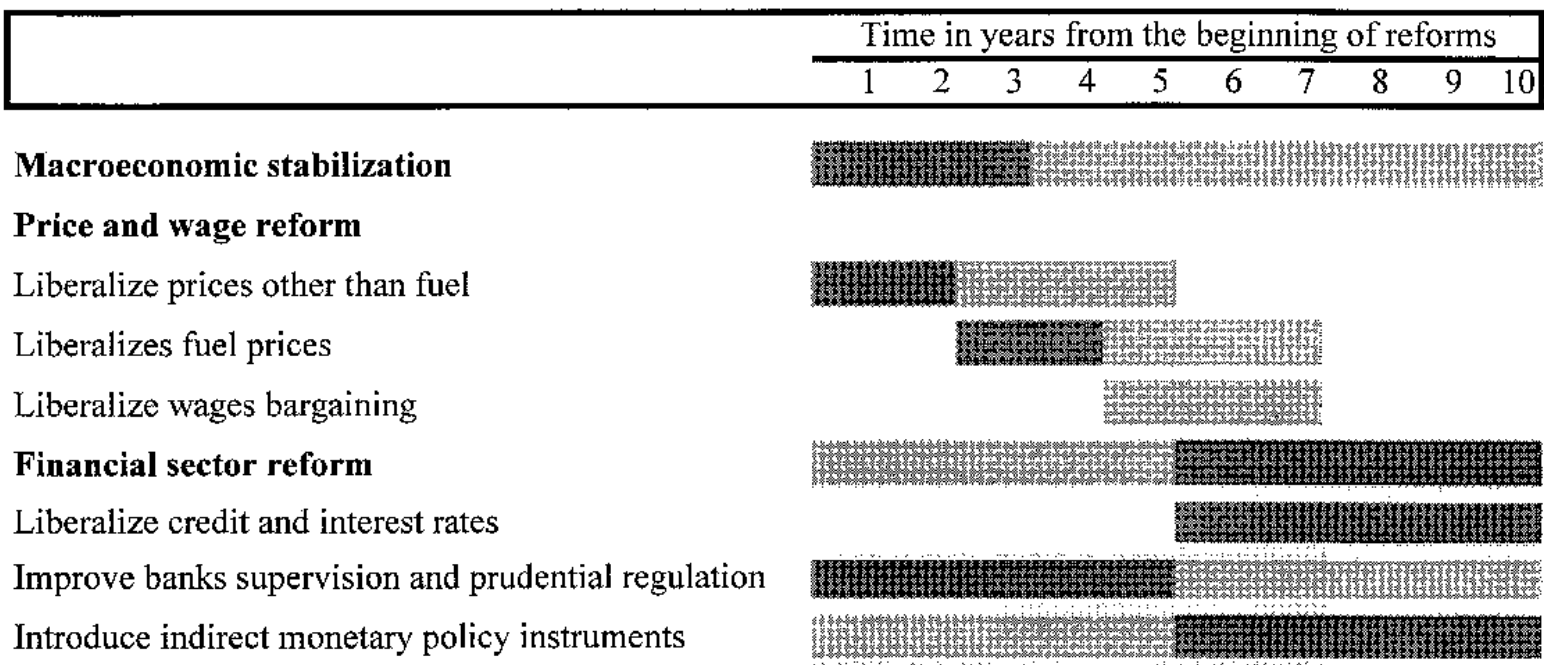

\section{Trade liberalization}

Remove quantitative restriction

Adjust tariffs to moderate levels

Exchange market reform

Unify exchange rate

Remove surrender requirements

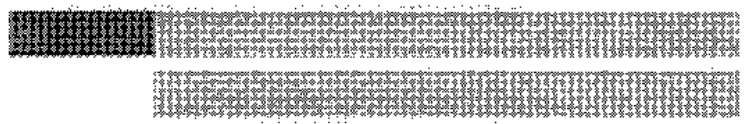

Privatization

Small-scale enterprises

Large-scale enterprises
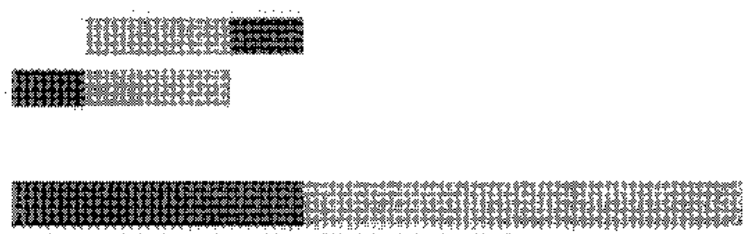

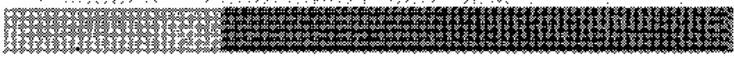

\section{Structural reforms}

Legal reform (tax, property, investment laws)

Institutional reform

Social reforms (unemployment insurance, education, et

Source: Developed based on Fischer and Gelb (1991).

intermediation only began in early 2000 , with the approval of the revised BOS Act. This act strengthened the independence of the central bank and revised the bankruptcy law and the law on auctioning mortgaged assets; this finally allowed banks to take ownership of the assets of defunct debtors. Small-scale privatization paralleled financial sector reform and, in the first stage, did not include banks - the step that could have provided additional dynamism to the financial reforms. Finally, price liberalization, which usually comes fairly early in the reform scquencing, was not completed until mid-1999, with some domestic prices for key petroleum products remaining controlled until 2000. 
Deficiencies existed in the sequencing of the financial sector reform itself. Restructuring and the privatization of state banks, which are largely responsible for the situation of distress in the banking sector and contribute to the high level of bad loans, should have preceded, or at least gone in parallel with, the liberalization of credit, exchange rate and monetary policies. Prudential regulation and bank supervision reforms have been delayed too long and, in fact, are still not completely in place. The experiences of other countries confirm that with a proper sequencing of financial reforms-including an early development of vigilant bank supervision and well-designed prudential regulations - the buildup of financial fragility might have been detected and contained. A minimal set of prudential reforms-including proper accounting rules for nonperforming loans, a good loan classification system and associated provisioning rules, capital adequacy guidelines, and limits on loan concentration - should have been set as an integral part of the early stage of macroeconomic stabilization. In any case, the development of a sound banking system, and of wellfunctioning prudential supervision, should have preceded the introduction of market-based monetary instruments. ${ }^{6}$ Moreover, the indirect monetary policy instruments have been introduced as part of macroeconomic stabilization, rather than as part of the financial reform, which should have followed it.

\section{B. Institutional Deficiencies}

The excessive role of the BOS in the banking system has discouraged the interbank market, competition, and market discipline. Inherited from the prolonged period of financial repression, the most distorting elements include the virtual management of the exchange rate by standing ready to level-off supply and demand in the market at a predetermined rate, and easily accessible general and overnight financing. Most banks prefer dealing with the BOS, where funding is easily available and settlement relatively efficient, in both overnight financing and foreign exchange operation. Psychologically, approaching another bank for funding is perceived as evidence of implicit weakness and discourages a bank's customers from placing funds with this bank. Continued sectorization of credit policy has remained largely unchanged since the early 1990s, although it is largely unbinding and much less restrictive than in earlier years. Nevertheless, in its annual monetary policy statements, the BOS continues to specify priority sectors with the by-bank floors on credit allocation ( 85 percent), nonpriority sector with the binding ceiling on credit allocation (15 percent), and sectors where banking financing is prohibited altogether (Figure 8).

\footnotetext{
${ }^{6}$ The experience of financial sector reform in Argentina, Chile, Indonesia, Korea, and the Philippines suggests that strengthening of prudential regulation should precede financial deregulation, although hardly any country succeeded in consistently implementing this principle in practice (see Sequencing Financial Sector Reforms, 1999).
} 
Figure 8. Sectoral Credit Policy, 1990-2000

$1990199119921993199419951996199719981999 \quad 2000$

Priority sectors $^{1 /}$

Agriculture

Exports

Industry

Mining and energy

Transportation and storage

Cooperatives

Professionals

Small producers and craftsmen ${ }^{2 t}$

Low-cost housing

Imports of medication and medical equipment

Investment in shares by banks

Culture and education

Services in rural areas

Nonpriority sectors ${ }^{2 /}$

Domestic trade

Services, other than those for primary sectors $\begin{array}{lllllllllll}90 & 90 & 90 & 90 & 90 & 90 & 90 & 90 & 95 & 90 & 90\end{array}$

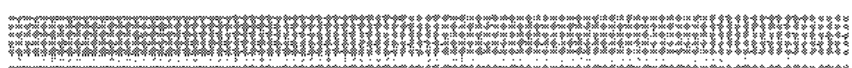

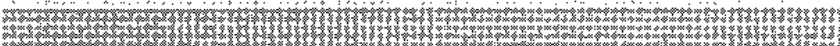

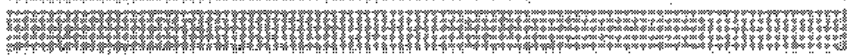

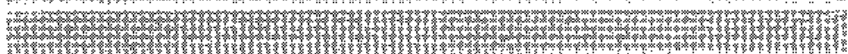

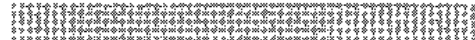

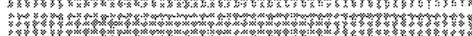

WW Why

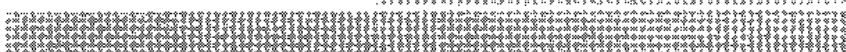

\%.

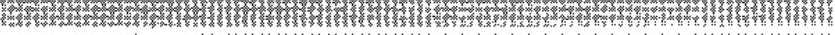
符期

7.1 3.

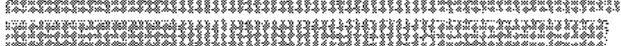

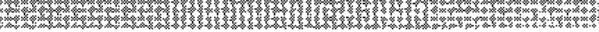

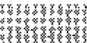

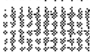

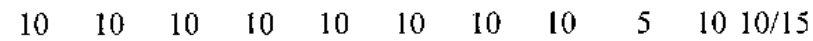

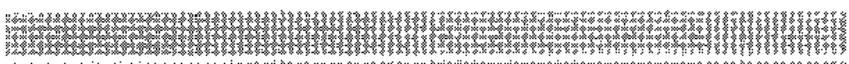

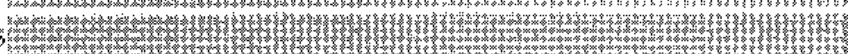

Activities prohibited for bank financing

Imports, except for primary sectors

Purchase of forcign currency

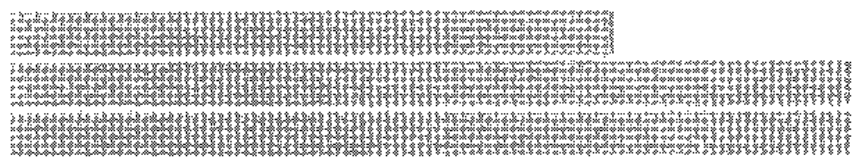

Purchase of shares by clicnts

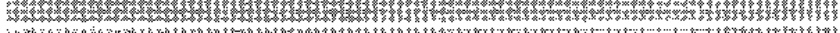

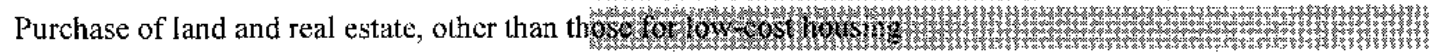

Foreign exchange bureaus

Source: Bank of Sudan.

1/ By bank floor on credit allocation in percent.

2/ The BOS sets a 7 percent nonbinding floor for credit allocation to small and family enterprises and craftsmen.

2/ Ceiling on credit allocation in percent.

Rules imposed by the Islamic financial system and exacerbated by the traditionalistic mentality may be excessive. Banking in Sudan faces a number of commercial, ethical, and legal impediments, which is one reason why, until now, the focus of their investment has been conservative and their financial products relatively unsophisticated (Box 3). 


\section{Box 3. Sudan: Limitations of the Islamic Financial System}

- Absence of the yield curve and the reference interest rate. The indirect cost of finance indicators-such as returns on investment deposits, Murabaha lending rate, rate of charge for the use of BOS financing windows, and the fair value of $\mathrm{CMCs}$ and GMCs - are formed on a highly segmented market, with little intersectional interflow of resources. They are calculated, either once a year (Murabaha) or quarterly (CMCs), and thus cannot be used by market participants as handy operational indicators.

- Operational limitations of the available Islamic mechanism of financing. Musharaka, the main mode of Islamic financing, is hardly applicable to agriculture, the main sector of the Sudanese economy. Musharaka envisages participation of both partners - the banks and their customers - in the management of the agricultural project, a task the commercial banks are reluctant to become involved in. Salem, the mode designed particularly for agriculture, can result in losses to banks if the repayment in-kind cannot be sold at above the value of the cash credit extended earlier.

- Difficulties in applying any charges, since all of them can be viewed as a kind of interest. No penalty can be applied to debtors with overdue loans. Charges for the use of BOS financing window are hard to calculate and enforce. These charges are usually calculated at the end of the year, after banks realize profit. During the year, the BOS gets - at best-a share of an estimated potential profit from the use of its resources by banks, but in most cases, it gets nothing.

- Problems using profit as a basis for calculating returns. Benefits to depositors should be based on actual profits generated by their investments, while any return, which is predetermined or calculated in some other way, is prohibited. As a result, no return is paid on current deposits, which by definition cannot generate profit. Only an investment account can pay a return to the depositors, and only if - and after-the bank realizes a profit. No return is paid otherwise, which may be discouraging for depositors.

- The incipient stage of Islamic accounting principles. Even with the introduction of Islamic accounting principles, banks face the difficulties of valuation of repayments in kind and other accounting problems, such as undeveloped accounting standards, and cannot apply the accounting experience of conventional banking.

- The existing modes of finance are still largely unfamiliar for conventional investors with no Islamic banking experience. Although many conventional banks in the world have an Islamic financial wing, the confusing, and often unwritten, rules for using particular contracts, such as Muzara or Ijara, which are often subject to freedom of religious interpretation, clearly narrow down the scope of potential investors from outside Sudan.

- The construction and introduction of new instruments of monetary policy, when based on Islamic principles, inevitably becomes excessively complex. Such instruments have to be based on a limited number of commercial, noninterest-bearing contracts, allowable under the Shari'a and must be approved by the Islamic Supreme Shari'a Council in addition to the conventional executive and legislative authorities. In particular, no form of financial derivatives, such as futures and options, are acceptable under the Shari'a, as they are viewed as a means of enrichment without hard work; no financial instruments with variable price-such as floatingrate loan — can be used, as they violate the principle of full disclosure.

Problems emanating from the inherent weaknesses of the payment system have not yet been properly addressed. With the large geographical size of the country and rudimentary interstate communications, the Sudanese clearing and settlement systems are inefficient. This manifests itself in lags in the settlements of money and exchange markets transactions, delays in check collection and data provision, poor accounting rules governing settlements, and a 
rudimentary level of communications technology. As a result, all banks have to keep up to 50 percent of their local currency deposits either in cash or as earmarked reserves, in BOS clearing accounts. The introduction of an interbank computer network, although progressing, is still at an incipient stage.

\section{Shallowness of Financial Markets}

High credit risks and the lack of competition among banks contribute to the high cost of borrowing. The BOS minimum Murabaha rate set at 15 percent is not binding, as all lending takes place at about 30 percent, and acts as a psychological instrument indicating to the markets the desirable rate level. The insufficiency of interbank competition is seen in the large spreads of Murabaha lending rates (13-34 percent) and returns on investment deposits, in particular, in foreign currency (8-20 percent). The reasons are numerous. A significant part of the banking system is still state owned, with privatization evolving slowly. Many banks continue to depend on BOS direct credits and refinancing. Market information is scarce, and the interbank market is used only sporadically to recycle excess funds, which precludes an efficient use of open market operations for monetary management. Inefficient banking technologies, uneconomical settlement systems, and deficiencies in the training of banking employees also contribute to the high cost of credit. In addition, any lending in Sudan remains genuinely risky, and the high rates of bank charges are to be expected.

The private deposit base is very weak for institutional and historical reasons. Under the limitations of the Islamic financial system, most banks cannot expand their deposit base quickly because most types of deposits are not remunerated. While in recent years the deposits have been growing in real terms, the share of investment deposits (the only type of deposits, which can be remunerated under the Shari'a) has remained unchanged in recent years at about 55 percent of total deposits. Since the 1991 exchange of local money, when the government imposed limits on deposit withdrawal, people have not trusted banks and prefer keeping cash at home. Moreover, the quality of many banking services remains substandard - in most cases cash is available only in small denominations in worn-out banknotes, lines are long, many banking employees are incompetent, and cases of forgery and cheating by bank clerks in cash withdrawals are common.

Sudan's banking system remains largely cut off from the international financial system. Sudanese banks' relations abroad are mainly limited to export finance and remittance transfers. Although some Sudanese banks have foreign shareholders, and there are a number of joint banks, the transfer of international experience has been slow, as investment in Sudan has not been justified on either political or security grounds.

\section{Role of Seasonality}

The seasonal profile of money demand, being broadly an exogenous factor, has not been changed by reforms, although some trends have become less pronounced, suggesting better BOS control of monetary movements. Three key seasonal factors affect money demand in Sudan-a demand for credit from the private sector, a transaction demand for 
cash associated with Ramadan, and a seasonal pattern of consumer prices. All three factors are closely interrelated and, in some periods, may partially offset each other. For example, prices for most food staples are high in the summer period (April-September) and low during the winter period (October-March), ${ }^{7}$ with the exception of Ramadan. Summer prices for some fruits and vegetables (e.g., tomatoes, lemons) can increase five times, while prices for meats and potatoes are subject to narrower fluctuations. Simultaneously, demand for credit increases before Ramadan and coincides with a higher transaction demand for cash (Figure 9).

Real demand for cash-which in Sudan is strongly affected by consumer-spending behavior before, during, and immediately after Ramadan-weakens BOS control over reserve money. According to the Islamic solar calendar, the dates of Ramadan shift backwards every year by approximately 12 days and lasts about 25-30 days (Figure 10). Higher consumer expenditure, and thus demand for cash, usually starts about a week ahead of Ramadan, as people get ready for the fasting period. It continues during Ramadan with particular high expenditure closer to its end, when all Muslims prepare to celebrate the major Islamic holiday, Eid El-Fitr. Thus, the seasonal trend covers approximately 1.5 to 2 months centered on the middle of Ramadan, which moved from March-April in 1992 to DecemberJanuary by 2000 .

Demand for cash increases during Ramadan, but if financed by the drawdown of banks' excess reserves, the impact on reserve money may not be very pronounced. Countercyclical movements in demand for cash and in banks reserves were particularly evident in 1996-99, when the overall impact of seasonal consumer behavior on reserve money during Ramadan itself was not very obvious. Starting a week ahead of Ramadan and continuing until the second week, demand for cash increases and banks reduce their excess reserves to meet this demand. In the second part of Ramadan, demand for cash declines, which allows banks to rebuild their reserves, but the demand grows again during Eid El-Fitr, thus generating the second countercyclical round in demand for cash and banks' reserves. In the month following Ramadan, banks usually rebuild their reserves - the trend particularly visible in the mid-1990s.

During the reform period, the span of Ramadan-related swings in demand for cash declined, suggesting improvements in BOS control of reserve money. In 1994-96, monthly swings in real growth of currency in circulation, and in particular banks' reserves, could easily exceed 30 percent; since 1997, these swings have not exceeded 10 percent on average. In December 1999, the seasonal demand for cash coincided with the buildup of banks' reserves, which led to an unprecedented expansion of reserve money, a phenomenon last observed in 1992 and 1994.

${ }^{7} \mathrm{X}-11$, ratio/difference from moving average all show prices above the centered average trend in June-September and below in October-May. 
Figure 9. Sudan: Seasonality in Monetary Aggregates, 1994-99

Credit to private sector

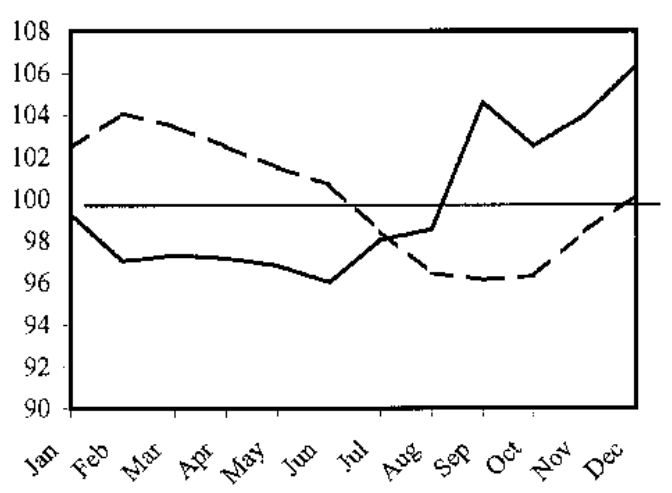

Credit to agriculture

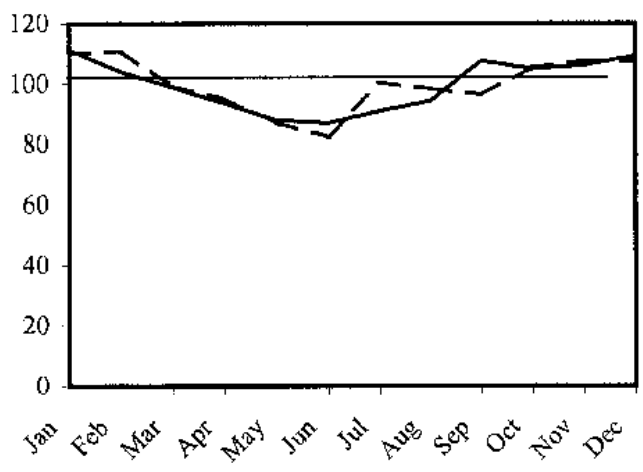

Credit to trade

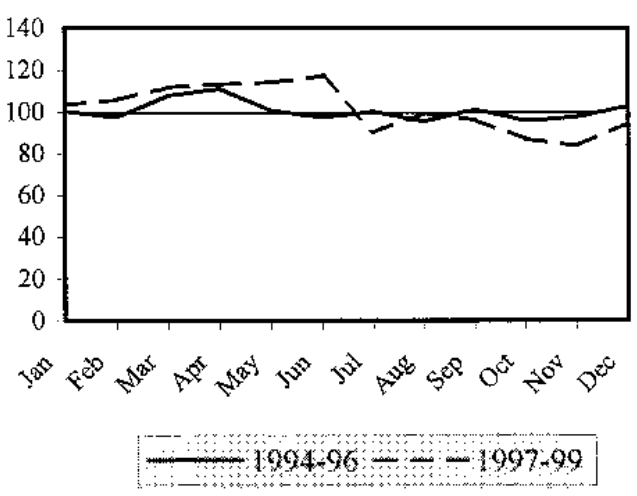

Seasonality in reserve money

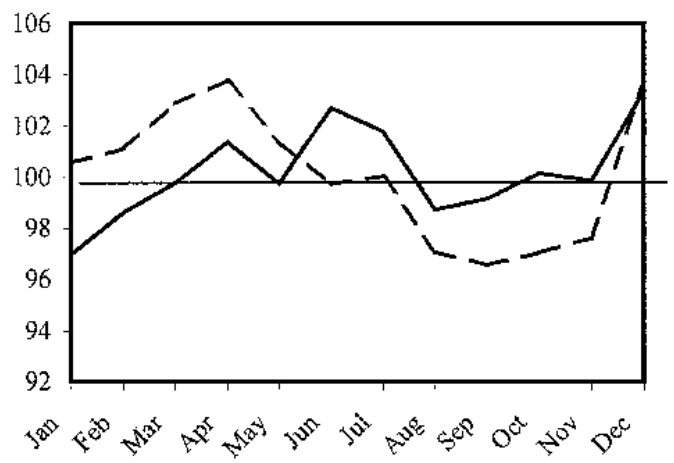

Currency outside banks

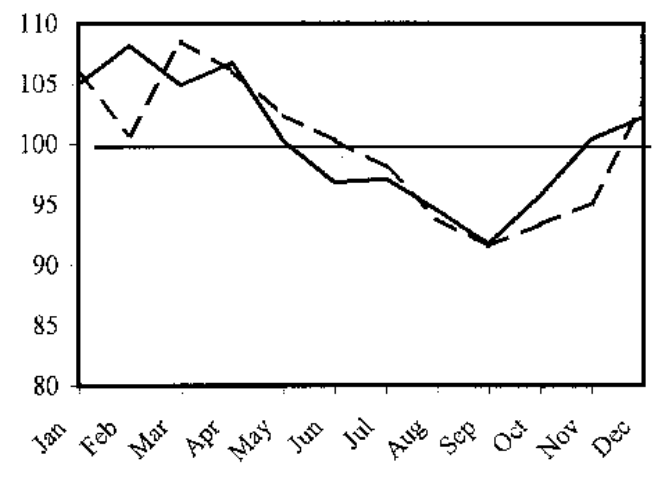

Banks' reserves

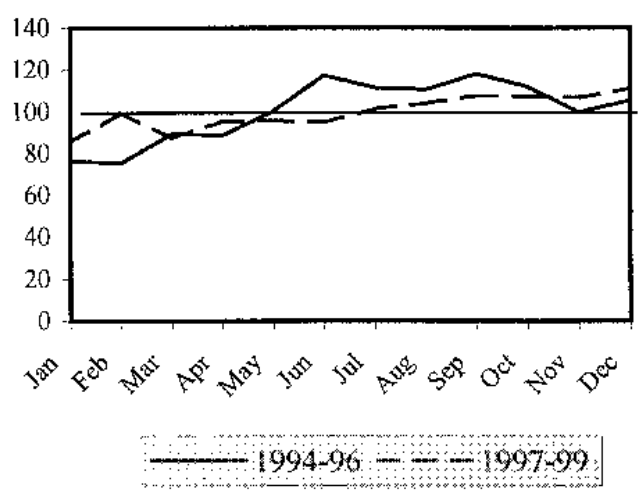

Source: Bank of Sudan and Fund staff estimates. 
Figure 10. Sudan: Ramadan-related Seasonality in Real Money Demand, 1991-99 (Real monthly growth in percent)
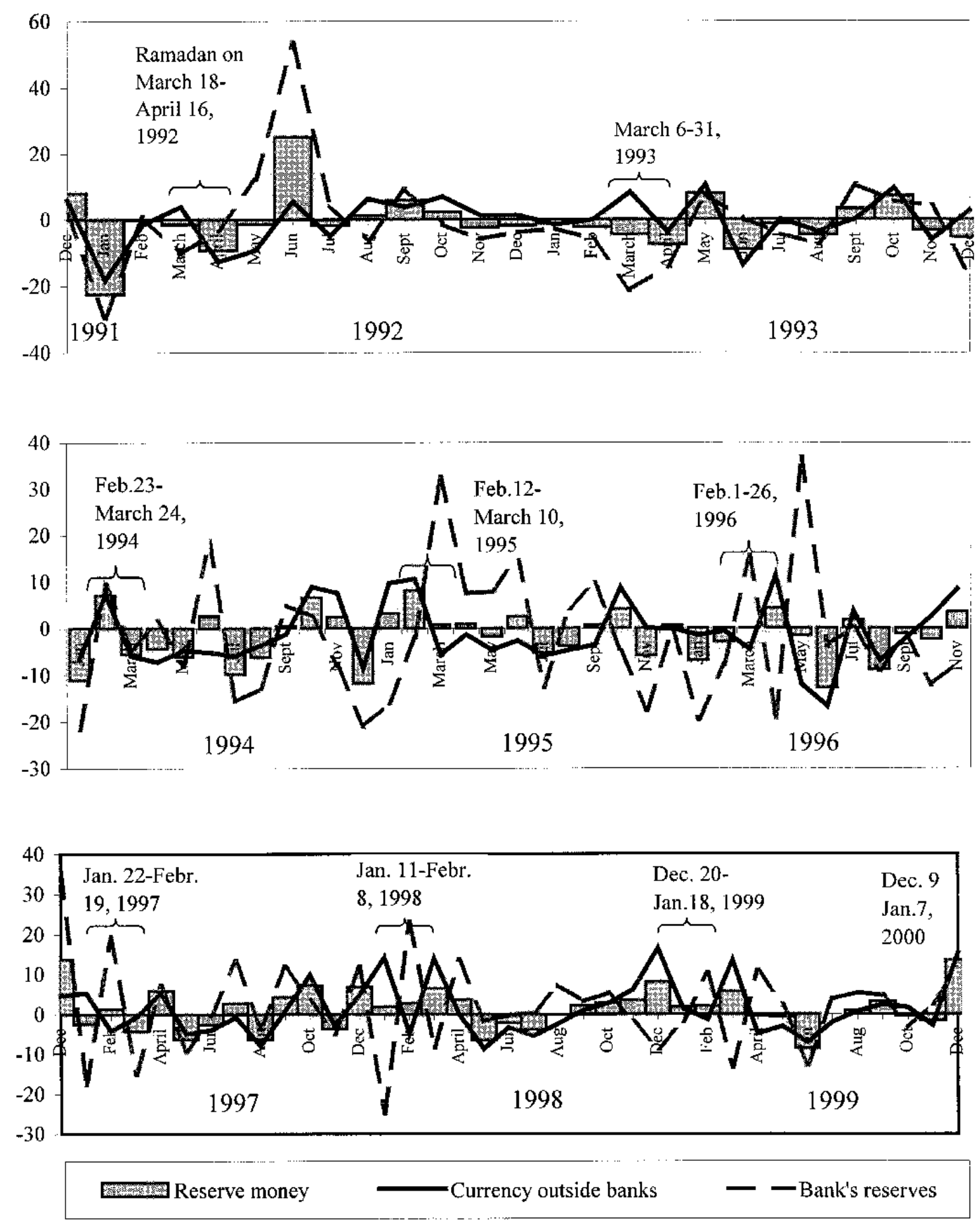

Source: Banks of Sudan, Islanic Calendar, and staff estimates. 


\section{Policy Challenges and International Experience}

In the immediate future, the BOS will have to deal with a number of challenges; adopting a more proactive monetary policy stance is the most important of them. During most of the reform period, monetary conditions have been tight. This has been due mainly to cautious government-borrowing policies, restrained by the ceiling on net borrowing from the BOS under the adjustment program agreed with the IMF. To a lesser extent, it was also due to deliberate BOS policies-the tightness of monetary policies itself reflected more the structural bottlenecks in the financial system than the efforts undertaken by the BOS. With the decline in government recourse to BOS borrowing and a more proactive BOS stance in influencing monetary conditions in the economy, any easing of monetary conditions is no longer viewed as just the pumping of additional liquidity, which may not be demanded by market participants. Rather, a vigorous pursuit of bank restructuring policy could alleviate the obvious clots in credit extension and bank portfolios. The pace of future reforms, tailored to the ability of the banking system to digest innovations, is clearly preferable to the abrupt introduction of new regulations and, in particular, to an excessive liberalization, which would inevitably expose banks to unknown market risks. Without adequate internal control and risk assessment procedures in place, this can be potentially detrimental to financial stability.

Preserving competitiveness of the traditional sectors by striking an appropriate balance between the desirable inflation rate and exchange rate appreciation while using the effective exchange rate as a guiding indicator, represents another challenge for Sudanese monetary management. While the standard "Dutch disease," undermining the competitiveness of the traditional sectors, still looks like a remote possibility, early experience suggests a substantial change in overall monetary conditions since late 1999. Recently, growing money demand has been satisfied by the increase in capital inflows, while domestic sources of money supply have been largely inactive, thus partly sterilizing such inflows. In Sudan, as in most countries undergoing a resource boom (currently, Azerbaijan, and earlier, Ecuador, Indonesia, and Nigeria), the desirable level of sterilization is not immediately obvious - excessive sterilization when money demand is growing parallel to the size of the economy will lead to nominal appreciation and will depress real growth, while a loose sterilization policy may undermine the credibility of the stabilization program by allowing excessive money supply and, thus, accelerating inflation. While some real appreciation is clearly warranted by the increase of overall wealth with the start of oil production, the moment it starts hampering competitiveness needs to be detected on time. With the anti-inflationary monetary policy in place, the trend toward real appreciation can then be curbed by stimulating domestic saving to substitute foreign capital as a source of productive investment.

Monetary conditions in the medium term will be heavily challenged by ways the government spends and saves its new oil revenue. Among other countries' practices regarding accounting for oil revenue- leaving it with the oil company, transferring it directly to the budget, depositing it into an account at the central bank, or creating a special oil trust fund - the policy adopted in Sudan of depositing-government share in oil revenue in a special 
oil account with the BOS look clearly preferable. This falls within a transparent accounting framework, less prone to distributive irregularities. The saving of oil revenue in a BOS government account with a counterpart increase in foreign assets does not affect reserve money and thus has no inflationary impact. At the same time, spending oil revenue on current consumption and large investment in oil-related activities with lax monetary control, as in the case of Mexico in early 1970s, led to real appreciation and a Dutch disease. Indonesia, in the 1980s, on the contrary, saved most of its oil windfall, accumulated budget surplus, and used it on investment in traditional sectors (agriculture) and foreign debt repayment. Coupled with better monetary planning, when the central bank released funds from the oil account smoothly to the budget within an agreement with the government fiscal schedule, such a policy largely avoided any visible inflationary impact and the Dutch disease (Usui, 1998).

\section{Selecting an appropriate operational target within a more comprehensive monetary} framework represents another challenge for the BOS monetary management. In the absence of explicit interest rates in an Islamic financial context, the BOS may target one of the monetary aggregates or one of their components. In terms of key criteria distilled by international experience - measurability, controllability by BOS, and predictability of impact on money supply - banks' reserves are a more preferable target for monetary policy than reserve money. While demand for currency is highly seasonal and affected by shifts in public sentiments between cash and deposits, the BOS directly controls bank reserves through statutory reserve requirements, open market operations, and investment lending. In general, the BOS can either target a certain quantity of reserves, allowing the availability of loanable reserves to influence the markup profit banks charge their customers on the resale of a Murabaha contract, or the price of reserves by adjusting their supply to meet demand for credit at the desirable Murabaha rate. Moreover, movements in banks' reserves will be better predicted-increase in demand for currency is usually associated with draining reserves, public deposits at commercial banks usually increase close to salary days which add reserves, etc. The selection of an operational target does not put BOS under any legal obligation to achieve it, but rather requires it to ensure that the level of credit to economy has been consistent with the chosen growth objective.

\section{The BOS will face the challenge of finding a practical way of managing the high and} volatile public sector deposits on its accounts, which is important for more efficient BOS control of reserve money. Out of the three possible frameworks suggested by the world experience for neutralizing the impact of deposit swings on reserve money - open market operations, moving public deposits outside the central bank, and shifting of public deposits between the central and commercial banks - each can be used by BOS, although with significant limitations. ${ }^{8}$ The BOS ability to neutralize movements in public deposits by means of open market operations, as is done in Armenia, Jordan, Kazakhstan, Malawi, and New Zealand and, is limited because, in 2000, such deposits were about five times larger

${ }^{8}$ Location of Government Deposits: Implications for Monetary Operations. IMF, 1999. 
than the combined BOS holdings of CMCs and GMCs available for open market operations. If legal impediments are removed, public sector deposits, at least the most volatile part of them, can be moved outside the BOS and held with commercial banks; this is the practice in Argentina, Kuwait, Qatar, and some other Gulf countries, and it is increasingly followed in Sudan with depositing funds for salary payments with commercial banks. Finally, shifting public sector deposits from the BOS and to commercial banks, as in Malaysia, can be used by the BOS as an instrument of monetary policy on its own, in addition to smoothing swings in public sector deposits.

While the demand for conventional banking is clearly present in Sudan, the BOS will face a challenge of introducing some elements of conventional interest rate-based banking parallel to Islamic banking. The availability of some modalities of conventional banking could be useful from both macroeconomic and banking services perspectives. On the macroeconomic side, the existing full Islamic system, which prohibits the charging of ex-ante determined interest, essentially equates rate of interest (price of money services) to rate of return (earning on investment). Thus, it recognizes only one feature embodied in interest rates (rate of return on physical assets), while completely ignoring the other (rate of return on financial assets), which is critical for monetary management in the short and medium run. Rate of return on financial assets is an opportunity cost for holding money, and thus is an indispensable element for accurate money demand projection. On the banking services side, some elements of conventional banking would help accommodate demand for such services from both the Sudanese and the expatriate communities, and would enhance the maneuverability of monetary management. In addition to Sudan, there are only two other countries-Iran and Pakistan-that have fully adopted the Islamic financial system.

Approximately 50 other countries, where Islam is a predominant or an important religion, operate conventional interest-based banking systems alongside Islamic banking. Among these countries, with experience particularly relevant to Sudan, are Bangladesh, Egypt, Indonesia, Jordan, Malaysia, and Syria (Abdul Gafoor, 1995).

Islamic banking itself is still in its infancy and needs to be developed and enriched to meet the requirements of a modern economy. Like any other system, the Islamic financial system is capable of evolution and allows innovation within the constraints set by Islamic principles. Undoubtedly, usury is forbidden, but modern interest rates cannot be unreservedly reduced to usury only. A practically useful distinction could be made between a normal charge for use of capital ( ${ }^{-16}$, interest ${ }^{9}$ ), which is allowed, and an excessive charge

\footnotetext{
${ }^{9}$ Interest (Middle English, $15^{\text {th }}$ century) is a charge for borrowed money, generally a percentage of the amount borrowed; the profit in goods or money that is made on invested capital or an excess above what is due or expected (Merriam Webster's Collegiate Dictionary, $11^{\text {th }}$ edition).
} 
( *) , usury ${ }^{10}$ ), which is prohibited. Interest should mean just a fair rate of charge, whereas usury should imply unfair charge. Whether usury exists can be determined only within the specific context of a particular transaction. As recognized by some Islamic scholars (Hammad, 1989; Trenk, 1990), a number of interest-based modalities of financing are possible under Islam. Furthermore, since GMCs and CMCs interfere with the privatization program by locking in the underlying assets, the government should accelerate the introduction of new instruments (such as the Ijara or Sukuk Salam) to replace the existing certificates. Finally, if a crop insurance scheme and future markets for commodities (which are possible under Islamic Law) were introduced, credit risks would be reduced and Islamic instruments could, in theory, meet the needs of agricultural financing. Overall, since deposits cannot be remunerated with a fixed interest rate, but only on a loss-and-profit-sharing basis, a private sector economy, free of government distortions, is the optimal environment for a system based on Islamic banking.

The problem of declining credit to the private sector remains a systemic challenge for monetary management in Sudan, and needs to be addressed mainly through structural reforms and new instrument design, rather than through administrative measures. Reintroducing direct BOS financing for public enterprises and imposing a binding ceiling on credit to undesirable sectors would introduce additional distortions into the banking system and are not conducive to private credit expansion. International experience shows that possible structural reforms could include setting up a system of credit risk insurance, hedging risks price fluctuations through commodity exchanges, developing additional Islamic modes of finance, and encouraging bank syndication for sizable loans and diversification of their credit portfolios. Bangladesh Islamic Bank, Jordan Islamic Bank, and Bank Islam Malaysia are three of the very few Islamic banks that have managed to diversify their loan portfolio considerably to include substantial manufacturing financing (Ausaf, 1987; Aggarwal, 2000). Problems with excessive credit directed to local trade reflect the fact that Murabaha is essentially a short-term instrument, mostly suitable for trade, rather than investment financing; while other long-term financing instruments, applicable to financing sectors other than trade, are virtually nonexistent, a situation which is recognized by many Islamic scholars as very unsatisfactory.

${ }^{10}$ Usury (Middle English, $14^{\text {th }}$ century) is the lending of money with an interest charge for its use; especially the lending of money at exorbitant interest rates an unconscionable or exorbitant rate or amount of interest; specifically interest in excess of a legal rate charged to a borrower for the use of money (Merriam Webster's Collegiate Dictionary, $11^{\text {th }}$ edition). 
Sudan needs to address the challenge presented by the genuine risks of lending to the private sector, in particular to agriculture. International experience shows that establishing a commodity exchange in agricultural products represents one of the market's means of hedging risks and protecting farmers against price volatility. "I Such a commodity exchange could serve the following purposes: price discovery, dissemination of information about expected future prices for agricultural commodities; hedging by protecting the prices of agricultural commodities by offsetting positions in cash and future markets to reduce the risk of unfavorable price movements; speculation by accepting risks and profiting from price movements. Among all Sudanese agricultural commodities, only cotton should not necessarily be traded through a future KCE because the existing channels of its export have been functioning satisfactorily. All other major crops-gum Arabic, groundnuts, and sesame-could be traded at a stock exchange to ensure correct pricing, hedging price risks, and adherence to international quality standards. Potential impediments are that future contracts are forbidden under the Shari'a (people cannot sell what they do not own), and the appropriate Islamically acceptable modalities for $\mathrm{KCE}$ have yet to be developed.

The implementation of a comprehensive program of bank restructuring remains a major challenge and an immediate priority. Bank restructuring is a lengthy and tedious process and is critical to maintain the momentum gained in the late $1990 \mathrm{~s}$. The bank restructuring reform is still in its infancy and, following the international experience, has to go through a number of stages, typical for most bank restructuring programs. ${ }^{12}$ At the initial stage of a financial reform, the monetary authorities usually create a legal framework for bank restructuring; completely liberalize the banking sector, deal with major nonperforming loans, review and adjust banking supervision; start working on achieving capital adequacy; start using reserve requirements as an active monetary policy instrument; strengthen licensing and entry regulations; initiate external auditing of major banks; start simple financial restructuring of banks by restructuring their loan portfolio. Sudan has almost completed this stage. At the next stage, the monetary authorities enhance using market-based instruments for monetary management; ensure capital adequacy through recapitalization, merges or liquidation; clean bad debt through loan recovery, workout arrangements and write-offs; revise accounting standards; and phase in key prudential regulation consistent

${ }^{11}$ Many agricultural countries have commodity exchanges and their experience can be used in Sudan. In the United States: CBOT (grains and oilseeds), CME (livestock and meat), CSCE (cocoa, coffee, sugar), KCBT (wheat, sorghum), MidAm (corn, oats, live cattle, hogs). Other countries with developed commodity exchanges include Australia (live cattle), Brazil (live cattle, coffee, cotton), Canada (grains, canola, barely, rye), France (sugar, cocoa, coffee), Japan (cotton, yarn), South Africa (Wheat, grains), United Kingdom (wheat, barley, potatoes, pigs, live cattle). In developing countries-Hong Kong (soybeans, sugar), Malaysia (food and fiber, palm oil, rubber), Singapore (rice).

${ }^{12}$ Sequencing Financial Sector Reforms. Country Experience and Issues. Ed. By Barry Johnston and V. Sundararajan. IMF, 1999 
with the Basle principles. Sudan has already taken a number of steps in this direction, in particular, by improving loan classification and provisioning, setting credit concentration limits and foreign exchange exposure rules. At the final stage of bank restructuring, open market operation and foreign exchange market become effective policy instruments, prudential regulation consistent with the Basle principles becomes operational, and the accounting and payment system reform is finalized. Sudan still has a way to go in this direction.

Faster transition from instrument-independence to policy-independence of the BOS is an important policy challenge for the overall structure of monetary management in Sudan. The BOS monetary policy, if geared toward forecasting and smoothing the shifts in monetary aggregates, should allow, at least in theory, for greater volatility of financial indicators and stand ready to mitigate it. The government, on its side, cannot expect the BOS to act outside the monetary field, such as support for priority sectors or budget financing. With the ultimate objective of the financial reform being to enable smooth implementation of monetary policies as a way to prevent disruptive business fluctuations emanating from the financial sectors that dampen growth, enhanced policy-independence would allow the BOS to persistently conduct market-based monetary policy. The government could contribute to enhancing BOS policy-independence by abstaining from intervening in credit policy and by converting its financing operations from a perpetual source of instability and uncertainty into a reasonably regular and predictable activity. 


\section{CONCLUSION}

Progress achieved by Sudan in financial reforms has been substantial, although still not sufficient to ascertain that the constraint on economic development emanating from the banking sector has been removed. The BOS has largely completed the liberalization of the financial system, introduced instruments of indirect monetary control, improved bank supervision and prudential regulation, and accelerated institutional reform. These efforts supplemented broader macroeconomic stabilization policies of the government and resulted in higher growth, reduction in inflation, exchange rate stability, and larger financial deepening. The trend of growing velocity has been reversed, and main monetary aggregates started rising in real terms; real rates of returns became positive, which stimulated growth in private sector deposits with commercial banks. Finally, the independence of the central bank has been strengthened, which allowed it to shift the priorities of its monetary policy from financing government deficits to price stability. At the same time, the financial reforms are far from being complete; the banking sector remains inherently weak, vulnerable to exogenous shocks and political instability. With the adherence to the de-facto fixed exchange rate regime, the BOS weakens its control of the behavior of reserve money, although by administering it intelligently, it could still accomplish a great deal. The instability of the multiplier creates an additional challenge for the authorities to make these basic tools in their monetary arsenal at least consistent with the ultimate goal of sustained real growth.

Continued strong macroeconomic policies and consistent financial reforms need to be mutually reinforcing. Rephrasing the famous dictum that the most effective way to destroy an economy is to destroy its money holds true in reverse as well - the most effective way to rebuild an economy is by rebuilding its financial system. There has been no severe depression anywhere in the world that was not accompanied by a sharp demonetization; conversely, there has been no successful recovery not followed by remonetization. A healthy economy is an indispensable precondition for a sound banking system, while strong banks are the veins for efficient intermediation, which is critical for economic health. Real effects of sound monetary policies have been historically systematic and economically significant. Sudan still has to reap their benefits.

Laborious work is still ahead for Sudan to create a modern financial system conducive to a high-quality growth. Overall, expectations should not be set too high - the financial reforms in themselves are not sufficient to spur high-quality growth. With the reform path adjusted intelligently to changing circumstances, the major gains one would reasonably expect are the following: effective insurance against banking disturbances, which may tear asunder the fragile Sudanese social fabric; more efficient resource allocation economy-wide, which is indispensable for growth; and some smoothing of short-term monetary swings, which are a recurrent source of uncertainty and instability. The BOS still has to steer the right course between the Scylla of what is acceptable from the point of view of the Shari'a and the Charybdis of application of conventional banking experience accumulated worldwide. Overall, as with any other economic reform, financial reform is one important face of the coin - the other is social progress. 


\section{ISLAMIC FINANCIAL INSTRUMENTS USED IN SUDAN}

Ijara is a contract under which banks can lease their assets to a third party. Types of Ijara:

- Muzara'a is a contract if hire of agricultural land, a crop-sharing contract whereby a client rents from a bank a plot of farmland for a specified period of time for cultivation. The resulting harvest is shared between the bank and the client according to a predetermined ratio.

- Muqawala is a contract of hire of labor, whereby banks provide materials and hire clients to process them.

Istisna'a is a contract of sale, used mainly for industrial finance, whereby the seller commits to produce a specific commodity at the request of the buyer, which pays its price either in advance or in installments according to the progress of work.

Mudaraba is a trustee contract whereby banks provide capital and clients provide labor for a joint project. The profit generated by the project is allocated between the bank and the client according to a predetermined ratio.

- Restricted Mudaraba is a contract whereby the bank requires that the clients invest its capital in a particular sector, project, or location.

- Unrestricted Mudaraba is a contract whereby the client is free to invest the borrowed capital at its discretion.

Murabaha is a purchase and resale contract whereby banks buy goods and resale them to the clients with a markup.

Musaqu'a is a partnership contract close to Musharaka, which potentially can be used to finance irrigated multiyear crops-dates, oranges, etc.

Musharaka is a partnership contract whereby the banks and the client contribute jointly to finance a project. Types of Musharaka:

- Continued Musharaka is a partnership contract whereby banks and clients jointly execute a project from beginning to end.

- Musharaka in working capital is partnership contract whereby entrepreneurs and banks provide parts of working capital, which is treated in this case as a separate project.

- Diminishing Musharaka is a partnership contract whereby the client has the right to gradually buy the share of the bank's ownership in the project and become the sole owner.

Salem is a contract of sale, used mainly in agricultural finance, whereby banks pay in advance to agricultural producers while the delivery of the commodity takes place in the future.

Trading purposes is a transaction whereby banks purchase goods for themselves, without having a customer beforehand, with a view to reselling them in the future on the market. 


\section{Evolution of Key Elements of Banking SUPERvision}

Capital adequacy requirements. The BOS first introduced capital adequacy calculations in 1994 that were revised in 1999. The calculations of capital adequacy are made on a quarterly basis based on tier 1 and tier 2 capital of banks. Tier 1 capital includes paid-in capital, general, legal, special, and other reserves, and retained earnings. Tier 2 capital includes general provisions for loan losses up to 1.25 percent of risk-weighted assets, 45 percent of revaluation reserves for fixed assets, and net investments. The following assets-weighting scale applies:

- Zero: cash in banks' vault, foreign exchange, cash at BOS, cash with local banks, check for collection, credit to government, $\mathrm{CMCs}$ and $\mathrm{GMCs}$;

- 20 percent: cash at foreign banks, credit collateralized by property titles, purchased commercial paper;

- 25 percent: Salem goods kept for less that one year;

- 30 percent: credit collateralized by real estate; industrial goods purchased for commercial purposes and kept up to one year;

- 40 percent: goods purchased for commercial purposes and kept for 1-2 years;

- 50 percent: credit to local governments, credit collateralized by stored goods, industrial goods purchased for commercial purposes and kept for 2-5 years, credit collateralized by securities listed at Khartoum Stock Exchange (KSE);

- 100 percent: credit collateralized by clients' acknowledgement; agricultural goods purchased for commercial purposes and kept for more than 1 year; industrial goods purchased for commercial purposes and kept for more than 5 years; credit collateralized by securities not listed at KSE, other purchases on commercial paper, own shares, fixed and other assets.

In 1999, the BOS set the minimum paid-in capital of banks at SD 3 billion, while previously there had been no formal requirements in this respect.

Loan classification and provisioning. Before March 1999, the BOS required that all banks maintain the general provision of 2 percent, which applied to all loans and was charged to current income before taxes, and of 5 percent for all nonperforming loans, regardless the classification. Since March 1999, in addition to the general provision which remained unchanged, the BOS established the following specific provisions for losses from nonperforming loans:

\begin{tabular}{|l|l|l|}
\hline Type of loans & Period overdue & $\begin{array}{l}\text { Level of Provision } \\
\text { (percent) }\end{array}$ \\
\hline \multirow{2}{*}{ Substandard loans } & Overdue for 1-3 months & 4 \\
\cline { 2 - 3 } & Overdue for 3-6 months & 6 \\
\hline Doubtful loans & Overdue for 6-12 months & 8 \\
\hline Bad loans & Overdue for over 1 year & 10 annually \\
\hline Perished debts & & 100 \\
\hline
\end{tabular}


For bad loans, banks has to provide 10 percent for loans overdue for more than one year annually until it reaches the total amount of the loan. all perished loans should be provisioned at 100 percent. The BOS classifies all loans overdue for over 1 month as nonperforming loans.

Internal liquidity ratio. All banks are required to maintain at least 10 percent of all its current and saving deposits and clearing balances in vault cash, as well as 50 percent of the balance of check issued, to meet the demand of deposit withdrawals. Banks' reserve requirements (see Attachment II) are also used as a prudential instrument. Reserves held to meet the liquidity ratio and the required reserve requirements are not remunerated.

Credit concentration limits. Since March 1999, maximum credit in local and foreign currency to a single borrow cannot exceed 25 percent of total bank's capital and reserves. This share applies to all bank's clients as well as to its Board of Directors, shareholders with a stake exceeding 7 percent of the bank's capital, senior management, bank subsidiaries with the bank's ownership of above 51 percent and affiliate companies with a bank's share of 20 51 percent. Total credit to Board of Directors collectively must not exceed the bank's capital and reserve of 10 percent of its credit portfolio, whichever is greater.

Foreign exchange exposure limits. Since February 1998, the limit was set at US\$ 50,000 for small banks and US\$100,000 for large banks in all currencies. Any long position exceeding the limit must be sold within the next business day, any excess short position to be offset within $2-3$ business days.

Off-site supervision. All banks are requested to submit to the BOS the following information

- Daily: current account balance with BOS

- Weekly: internal liquidity ratio; legal reserves in local and foreign currency

- Monthly: loans by type and sector, balance sheet, letters of guarantees, nonperforming loans, loans outstanding, loans to insiders, loans to bank affiliates, loans by financial institutions, loans in foreign currency during the past month, unsettled prior loans in foreign currency

- Quarterly: capital adequacy ratio, loan classification and provisions

- Annually: final balance sheets and other accounts.

On-site examination. The OS performs periodic comprehensive or restricted inspections of banks, targeting specific irregularities.

Licensing. The BOS issues and revokes bank licenses under the Banking Law. 


\section{EVOLUTION OF MONETARY POLICY INSTRUMENTS}

Reserve requirements. Through the 1990 s, reserve requirements have been applied by the BOS on current and savings deposits, as well as on margins of letters of credit in local currency. In the early $1990 \mathrm{~s}$, the BOS set the reserve requirements set at 20 percent and gradually raised them to 25 percent in 1996 and 30 percent in 1997 percent before reducing them to 28 percent in 1998-99. Since 1997, reserve requirements apply also to foreign currency deposits. For 2000 , the reserve requirements were originally set at 20 percent of local currency deposits as reflected in banks' weekly position statements provided to BOS and at least 10 percent of foreign currency deposits to be maintained in foreign currency. Since July 2000, the BOS unified reserve requirements on local and foreign currency deposits at 15 percent and further reduced them to 12 percent in 2001 . The calculations of required reserves are based on deposits held in banks' branches in the State of Khartoum only, which are reported to BOS within two working days after the 7 th, $14^{\text {th }}, 21^{\text {st }}$, and the last day of each month. The BOS adjusts banks' blocked accounts with the BOS compulsorily to ensure each bank's compliance with the reserve requirements, which are not remunerated.

Financing windows are BOS standing facilities used to provide financing to banks at their request. Available through the 1990 s, the unexpected deficit-financing window was supplemented in 1998 by the expected deficit-financing window and the investmentfinancing (general financing) window. Since 2000, the unexpected and expected deficit financing windows have been combined into the liquidity deficit-financing window, while the investment financing window remained unchanged.

- Liquidity deficit financing window can be activated by banks experiencing a liquidity shortage on a particular day, as manifested by low cash holdings in their vaults or by overdrawn accounts at the BOS clearing house. At the request of an interested bank, the BOS credits its current account with the BOS by the amount requested or overdrawn, which cannot exceed 10 percent of the bank's current deposits in local currency in the previous week. In 1999, the duration of this financing was reduced to one week, from two, renewable once upon additional request for another week, after which the BOS automatically deducted the loaned amount from the bank's current account. The financing is free if repaid within one week. For any financing exceeding one week, the BOS charges banks 90 percent of their profits received from using its financing during the whole period. This is a penalty rate because under an average profit-sharing agreement with their clients on regular investment deposits, banks appropriate about 30 percent of the profit received. The number of applications for this kind of financing is limited to two in a month and to not more than four in three months, and the actual use of the window is not very intense-only four banks had recourse to it in 1999 and 2000.

- Investment financing window is used by the BOS as either a general financing tool to close the economy's funding gap (by mode of unrestricted Mudaraba/Musharaka), or as financing for priority sectors and projects (restricted Mudaraba). The old system of providing direct BOS financing to banks and public enterprises has been abolished, and 
since March 2000 the BOS has been auctioning finance through a competitive auction. The bidding variable is the share of profit received by competing banks from the use of financing, which they would be ready to give up to the BOS at the end of the year. Requirements on banks to qualify for participation in auctions: nonperforming loans not exceeding 20 percent of their total credit outstanding, the returns paid on investment accounts of not less than 18 percent, not drawing on financing from the liquidity financing window during the past year.

Open market operations (OMO) started in 1998 when the BOS issued CMCs specifically designed as a tool for OMO. In 1999 the Ministry of Finance issued GMCs, with the primary goal of financing the budget. Part of GMCs was transferred to the BOS in 2000 for the use as an additional tool for OMO. Both instruments are based on a Musharaka contract, under which the investors share profits generated by underlying funds.

- Central Bank Musharaka Certificates (CMCs) are designed as a short-term highly liquid paper with no maturity for smoothing short-term fluctuations of liquidity and traded at a very short notice by the BOS and commercial banks only. The BOS trades CMC with banks at weekly buy and sell auctions and on-demand, sells CMCs to mop up excess liquidity and repurchases them at a small markup of about 2 percent on an annualized basis. The face value of CMCs is SD 1 million, and their fair value is calculated quarterly on the basis of the profits of the underlying funds consisting of the BOS share in commercial banks.

- Government Musharaka Certificates (GMCs) are designed as a medium-term paper with one-year maturity traded by BOS on behalf of the government to all investorslocal and foreign, public and private, bank and nonbank, corporations and individuals. The underlying GMC fund includes state-owned enterprises. The face value of GMC is SD 500 million. GMCs are issued in tranches and sold at auctions. First tranche was redeemed at maturity in February 2000 at a 34.2 percent profit to investors. Although demand for GMCs is picking up, there have been no OMO in GMCs yet.

Setting of minimum rates is used by the BOS as a tool to regulate the cost of borrowing during the 1990s. The BOS sets the floor rate, rather than the ceiling, that is used mainly as a tool of moral suasion to signal the stance of monetary policy to banks, which are expected not to exceed the minimum rates significantly.

- Minimum profit margin under Murabaha contract sets the minimum cost of financing for borrowers. In the mid- $1990 \mathrm{~s}$, the BOS applied differentiated minimum rates of 30-50 percent to different sectors, which were unified in 1998 at 36 percent, and reduced to 20 percent in 1999 . In 2000 , the rate was further reduced, first to 18 percent, and then to 15 percent and 12 percent in 2001 for financing in local currency and to 10 percent for loans in foreign currency. Actual lending rates also followed the indicated pattern and declined from 30 to 25 percent in the first quarter of 2000 . 
- Minimum share of customers' participation under Musharaka contracts was used until 1998 as a means of regulating the volume of available loanable resources and was abolished thereafter.

Foreign exchange operations is a monetary instrument available in principle to the BOS. In 1997-99, before the CMCs became operational, the BOS in several occasions used purchases and sales of foreign exchange for purposes of regulating liquidity. But currently, as the BOS stands ready to buy and sell foreign exchange on demand targeting the exchange rate stability, foreign exchange operations largely lost their liquidity control functions. 


\section{References}

Abdallla, Ahmed Ali, 1997, "Islamic Modes of Finance: Origins, Principles, and Legal Rules," Bank of Sudan Bulletin.

Abdul Gafoor A., 1995, "Interest-Free Commercial Banking" (Netherlands: Apptec), pp. 78-81.

Afzal, Mohammad, 1993, "Theory and Practice of Islamic Banking: Pakistan Economic and Social Review" (Pakistan), Vol. 31, pp. 102-117.

Aggarwl, Rajesh and Yousef Tarik, "Islamic Banks and Investment Financing," Journal of Money, Credit, and Banking, Vol. 32, No.1, pp. 93-120.

Al-Loughani, Nabeel E., 1996, "A test of the Money Multiplier Model for a Small Open Economy: the Case of Kuwait," Savings and Developments (Italy), Vol. 20, No. 3, pp. 315-25.

Al-Omar, Fuad, 1996, Islamic Banking: Theory, Practice, and Challenges, (Atlantic Highlands, NJ: Zed Books).

Askari, Hossein, 1995, Opportunities in Emerging Islamic Financial Markets, Banca Nazionale del Lavoro (Italy), Quarterly Review, Vol. 48, pp. 255-82.

Ausaf, Ahmad, 1987, Development and Problems of Islamic Banks: Jeddah, Saudi Arabia, Islamic Research and Training Institute and Islamic Development Bank, p. 152.

Ausaf, Ahmad, 1997, Structure of Deposits in Selected Islamic Banks: Implications for Deposit Mobilization, Islamic Development Bank, Islamic Research and Training Institute (Jeddah).

Bank for International Settlements Policy Papers: "The Transmission Mechanism of Monetary Policy in Emerging Market Economies," Policy Paper No. 3 (January 1998), "Monetary Policy Operating Procedures in Emerging Market Economies," Policy Paper No. 5 (March 1999), "Bank Restructuring in Practice," Policy Paper No. 6 (August 1999).

Bank of Sudan, Monetary and Financing Policy Statements for 1991-2000; Annual Reports, 1994-1999; Circulars on Monetary and Credit Policy, 1997-2000.

Barkoulas, John T., Christopher F. Baum, and Mustafa Caglayan, 1999, "Fractional Monetary Dynamics," Applied Economics No. 11, pp. 1393-1400 (U.K.). 
Basha, Zakaria A., 1990, "Development of Islamic Banking and the Money Multiplier Process," Orient/Deutsches Orient-Institut No. 3 pp. 389-401 1990 (Germany).

Bendjilali, Boualem, 1996, On the Demand for Consumer Credit: An Islamic Setting.

Building on Progress: Reforms and Growth in the Middle East and North Africa" 1996, (Washington: International Monetary Fund).

Chapra, M. Umer (Muhammad Umer) [?], 1996, "What is Islamic Economics?" Islamic Development Bank, Islamic Research and Training Institute (Jeddah, Saudi Arabia).

Chowdhury, Abdur R., 1999, "The Velocity of US M2 in the 1990s: Some Further Evidence," Applied Economics No. 9, pp. 1137-44, (U.K.).

Dalziel, Paul, 1995, "The Keynesian Multiplier, Liquidity Preference, and Endogenous Money," Encyclopedia of Islamic Banking and Insurance (London: Institute of Islamic Banking and Insurance).

Errico, Luca and Mitra Farahbaksh, 1998, "Islamic Banking: Issues in Prudential Regulations and Supervision," IMF Working Paper 98/30 (Washington, D.C.: International Monetary Fund).

European Central Bank, 1998, "The Single Monetary Policy in Stage Three: General Documentation on ESCB Monetary Policy Instruments and Procedures."

European Perceptions of Islamic Banking, 1996, (London: Institute of Islamic Banking and Insurance) p. 135.

Fischer, Stanley and Gelb, Alan, 1991. Process of socialist economic transformation. Journal of Economic Perspectives (U.S.); Vol. 5, pp. 91-105.

Ford, J. L., 1996, "The Money Multiplier, Simple Sum, Divisia and Innovation-Divisia Monetary Aggregates: Cointegration Tests for the UK." Applied Economics (U.K.); Vol. 28, pp. 705-14.

Friedman, Benjamin M, 1999, The Future of Monetary Policy: The Central Bank as an Army With only a Signal Corps? Working Paper Series No. 7420, pp. 1-37 (November), National Bureau of Economic Research.

Friedman, Benjamin M., 1995, "Does Monetary Policy Affect Real Economic Activity? Why do we Still Ask this Question?" Working Paper Series No. 5212, pp. 1-39 (August) National Bureau of Economic Research. 
Friedman, Milton and Schwartz, Anna Jacobson, 1963, A Monetary History of the United States (Princeton, Princeton University Press).

Friedman, Milton, 1959, A program for Monetary Stability (New York: Fordham University Press).

Friedman, Milton, 1994, Money Mischief: Episodes in Monetary History (San Diego, California: Harcourt Brace).

Hammad, Alam al-Hudá, 1989, Islamic Banking: Theory and Practice, (Cincinnati, Ohio: Zakat and Research Foundation).

Handbook of Monetary Economics, 1990, ed. by Benjamin M. Friedman and Frank H. Hahn. (Amsterdam; New York: North-Holland).

Iqbal, Zubair and Abbas Mirakhor, 1987, Islamic Banking, Occasional Paper No. 49 (Washington, D.C.: International Monetary Fund).

Islamic Banking and the Functions of Universal Banks, 1994, Economic Bulletin No. 3:213-19 (Egypt: National Bank of Egypt).

Islamic Financial Instruments for Public Sector Resource Mobilization, 1997, ed. by Ausaf Ahmad and Tariqullah Khan (Jeddah, Saudi Arabia: Islamic Research and Training Institute, Islamic Development Bank), p. 414.

Ismail, Abdul Ghafar, 1994, "Monetary Policy and Commercial Banks: A Survey," Indian Journal of Economics (April) (India), Vol. 74, pp. 431-56.

Jangual, Hussein and Saiah Mohammed, 1999, "Monetary Policy Instruments in an Islamic System: Theory and Practice, (Case of CMCs)," Bank of Sudan Bulletin.

Journal of Post Keynesian Economics, (Spring) 1996 (Jeddah, Saudi Arabia: Islamic Research and Training Institute, Islamic Development Bank).

Khan, Mohsin S. and Abbas Mirakhor, 1989, "Islamic Banking: Experiences in the Islamic Republic of Iran and Pakistan," IMF Working Paper No. 89/12 (Washington, D.C.: International Monetary Fund).

Khan, Mohsin S. and Abbas Mirakhor, 1994, "Monetary Management in an Islamic Economy," Journal of King Abdulaziz University, Islamic Economics, Vol.6.

Kharadia, V. C., 1993, "Money Multiplier, Currency Deposits Ratio and Monetary Policy: A Study of Developed and Developing Countries," Indian Journal of Economics (January) (India), Vol. 73, pp. 319-33. 
Maysami, Ramin Cooper, 1995, "Interest-Free Financial Activities in Indonesia, Malaysia, Bahrain, and Pakistan," Asian Economies (June) (Korea), Vol. 24, pp. $27-$ 45 .

Moore, Philip, 1997, "Islamic Finance: A Partnership for Growth," Euromoney Publications in Association with Abrar Group International (London).

Monetary and Exchange Affairs Department (Washington, D. C.: International Monetary Fund), Operational Papers.

O'Sullivan, Diarmid, 1996, "Islamic Banking: MEED Special Report," Middle East Business Weekly (July), Vol. 40, pp. 7-12

Rosenberg, Christoph and Tapio Saavalainen, 1998, "How to Deal with Azerbaijan's Oil Boom?" IMF Working Paper 98/6 (Washington, D.C.: International Monetary Fund).

Siddiqui, Shahid Hasan, 1994, "Islamic Banking-Some Recommendations," Journal of Islamic Banking \& Finance (July-September) Vol. 11, pp. 25-31.

Sequencing Financial Sector Reforms. Country Experience and Issues. Ed. By Barry Johnson and V. Sundararajan. IMF, 1999.

The Noble Qur'an, 1994, "Translation and Commentary by Dr. Muhammad Taqi-ud-Din Al-Hilali" Rijad: King Fahd Complex.

Wilson, Rodney, 1995, "Islamic Banking and its Impact on the International Financial Scene," Journal of International Banking Law No. 10, pp 437-445 (October).

Zaki, Mokhlis Y., 1995, "Forecasting the Money Multiplier and the Control of Money Supply in Egypt," Journal of Development Studies (October) Vol. 32, pp. 97-111. 